\title{
Arab-German Trade and Institutions: The Effect of Good Governance on Arab Exports to Germany
}

\author{
Mohamed Ismail Sabry ${ }^{1}$ (D)
}

Accepted: 5 August 2021 / Published online: 10 September 2021

(c) The Author(s) 2021

\begin{abstract}
Does good governance matter for exporting to the highly competitive markets of developed countries, especially those committed to a developmental mission centered on promoting good governance? This paper is investigating this research question. The focus of the analysis is the case study of Arab exports to the German economy, where a comparatively poor performance in comparison to that of other regions of the world is witnessed, despite geographical proximity and preferential trade agreements. Using statistical data and the literature on the subject, the paper engages in a discussion on German trade flows from Arab countries and whether governance indicators provide a good explanatory framework. The research question is then investigated empirically by running several regressions using the two-stage least-squares and Poisson pseudo maximum likelihood models. Different indicators of German exports are used as dependent variables while the independent variables are various governance indicators together with the control variables suggested by the gravity model. The obtained empirical results suggest that good governance generally boosts Arab exports to Germany and relatively more than it does for non-Arab exporters to Germany. This is especially true for governance indicators that directly affect exporting activities, such as regulatory quality and government effectiveness. For some indicators that indirectly affect exporting, however, the results are mixed for both Arab and non-Arab countries, especially for the textile industry. This sheds doubts on Germany's developmental commitment to fostering good governance principles.
\end{abstract}

Keywords Trade · Arab countries · Germany · Governance · Exports and imports · Institutions

Mohamed Ismail Sabry

misabry@hotmail.com

1 School of International Business, Bremen University of Applied Sciences, Werderstraße 73, 28199 Bremen, Germany 


\section{Résumé}

La bonne gouvernance est-elle importante pour exporter vers les marchés hautement compétitifs des pays développés, en particulier ceux engagés dans une mission de développement centrée sur la promotion de la bonne gouvernance ? Cet article étudie cette question de recherche. L'analyse se concentre sur l'étude de cas des exportations arabes vers l'économie allemande, où l'on observe une performance médiocre si on la compare à celle d'autres régions du monde, malgré la proximité géographique et les accords commerciaux préférentiels. À l'aide de données statistiques et de la littérature disponible sur le sujet, l'article s'engage dans une discussion sur les flux commerciaux allemands en provenance des pays arabes et sur la question de savoir si les indicateurs de gouvernance fournissent un cadre explicatif adéquat. La question de recherche est ensuite étudiée de façon empirique en exécutant plusieurs régressions à l'aide de la méthode des moindres carrés en deux étapes et de celle du maximum de vraisemblance de Poisson. Les variables dépendantes sont divers indicateurs relatifs aux exportations allemandes, tandis que les variables indépendantes sont divers indicateurs de gouvernance ainsi que les variables de contrôle suggérées par le modèle de gravité. Les résultats empiriques obtenus suggèrent qu'en règle générale la bonne gouvernance stimule les exportations arabes vers l'Allemagne et cela, relativement plus qu' elle ne le fait pour les exportateurs non arabes vers l'Allemagne. Cela est particulièrement vrai pour les indicateurs de gouvernance qui affectent directement les activités d'exportation, tels que la qualité de la réglementation et l'efficacité du gouvernement. Pour certains indicateurs qui ont un impact indirect sur l'exportation, cependant, les résultats sont mitigés pour les pays arabes et non arabes, en particulier en ce qui concerne l'industrie textile. Cela laisse planer un doute quant à l'engagement de l'Allemagne pour la promotion des principes de bonne gouvernance dans le cadre du développement.

\section{JEL Classification F14 · F19 · O43 · P48}

\section{Introduction}

Does good governance matter for trade? Does it boost export performance? Many works in the literature suggest that this is the case (see WB 2009; Nunn 2007; Anderson and Marcouiller 2002 and $\mathrm{Ng}$ and Yeats 1998). The implications for developing countries seem to be straightforward, seeking an export-oriented growth strategy necessitates institutional reform tackling governance-related aspects. Nevertheless, these claims are questioned by a body of literature resting on the not-toodistant experience of some East Asian countries. These countries pursued a successful export-led growth strategy under a "developmental state" (see Wade 2018 and Haggard 2015) whose practices contradicted with good governance premises and earned the label of crony capitalism (see Aligica and Tarko 2014 and Kang 2002).

The question of institutional reform is especially important for an export-led economic strategy targeting the highly competitive markets of developed countries. As one of the biggest five economies of the world and the biggest economy in the European Union (EU), access to the German market is a big objective for many 
developing countries. With imports of $\$ 1.24$ trillion in 2019 , representing more than $54 \%$ of EU imported goods (Comtrade 2020), increasing a developing country's share of total German imports would be translated into substantial economic and financial gains. Moreover, success in exporting to the German market could open the way for integration into the German gigantic industrial supply chain as well as to the markets of other EU countries. Efficiency and competitiveness seem not to be the only institutional reform motives when trading with Germany. The country officially proclaimed its international commitment to promoting good governance (see BMZ, BMZ 2030 Reform Strategy). This implies that higher performance in institutions such as control of corruption and voice and accountability should be rewarded by more access to German markets. Such strong commitment makes Germany a very valid case study, even in comparison to other EU states, for studying the effect of good governance institutions on trade and exporting to a developed economy. Even if the EU as an organization promotes good governance, the commitment and the resources available to its member states to achieve this objective greatly vary. Germany with its well-established developmental cooperation and aid record stands in a unique position, not only in the EU but also on a global scale.

On the other hand, the literature suggests that the Arab World is a region whose poor export performance could be attributed to institutional deficiencies (see Karam and Zaki 2019; Martinez-Zarzoso et al. 2016; Bhattacharya and Wolde 2010, p. 16 and Méon and Sekkat 2004). There is more than one reason that would suggest that the Arab World should have an active trade relationship with Germany. The first is the Euro-Mediterranean Partnership that started with the Barcelona Declaration of 1995 and called for freer trade between EU countries and the Arab region. ${ }^{1}$ Another is the comparative geographical proximity of the region to Germany. A third reason is the differences in factor endowments between both sides. Yet, figures suggest otherwise. Arab exports to Germany lagged behind most of the world regions' levels, including Central and South Asia, South America, and Sub-Saharan Africa (own calculation of data obtained from Comtrade). If preferential trade agreements and trade theories-from Heckscher-Ohlin to simple gravity models-fail to explain this poor performance, institutions-and especially governance-related ones-could be better explanatory factors.

This paper is investigating whether and to what extent varying levels of governance within the Arab world affect the region's export levels to Germany. It also explores which governance institutions boost these exports and which ones might harm them, accounting for the different theoretical perspectives on the subject. Many aspects underline the importance of this research. Firstly, the relationship between good governance and the export performance of the Arab countries has not been adequately researched. Secondly, the effect of some governance indicators such as voice and accountability (V\&A) on trade was often explored from the perspective of importing countries (see Berden et al. 2014) rather than exporting countries, as done here. Furthermore, while some works in the literature examined developed

\footnotetext{
${ }^{1}$ For a discussion on the success or failure of the Euro-Mediterranean Partnership in reaching its objectives, see Brach (2007).
} 
countries' sincerity in promoting good governance through foreign aid to developing countries (see Zanger 2000) opening up developed countries' markets as an incentive tool was hardly explored. On a wider scale, this study could be thought of as a case study that investigates the effect of good governance on developing countries' export opportunities in terms of accessing the markets of advanced economies, whether by enhancing developing countries' exporting capabilities or letting them be regarded favorably as reformers.

The empirical results of this paper suggest that good governance generally boosts Arab exports to Germany and relatively more than it does for non-Arab exporters to Germany. This is especially true for governance indicators that directly affect exporting activities, such as regulatory quality and government effectiveness. For some indicators that affect exports indirectly, however, the results are mixed for both Arab and non-Arab countries alike, especially for the textile industry. This sheds doubts on Germany's developmental commitment to fostering good governance principles.

The next section discusses the various theoretical perspectives related to the research question. This is followed by a section on our case study. It starts with an overview of Arab exports to Germany using the available statistical data. This is followed by a sub-section on the literature on governance institutions as explanatory factors for Arab export performance. The next section introduces the methodology which is then followed by a section on results. The paper ends with a conclusion that brings further insights and offers some policy recommendations.

\section{Theoretical Perspective}

The renowned Ricardian comparative advantage theory anticipated that even for a less efficient country, comparative advantage can be realized in the products which relatively cost less to produce (see Mankiw, 2015). The Hecksher-Ohlin model, on the other hand, suggests that countries would specialize according to their factor endowments (e.g.: labor, capital). Each country should produce goods that intensively use its cheaper and abundant factors of production and import goods that use intensively its expensive and scarce factors of production. ${ }^{2}$ An adaptation to this perspective is offered by Aghion and Howitt (1998, pp. 376, 387, 395) who have argued that the accumulation of knowledge and experience resulting from learning by doing would influence what each country would specialize in. A less developed country starting from a low initial technological basis would tend to specialize in less sophisticated products with low learning potential.

Another important theoretical perspective is provided by the gravity model. The model expects that bilateral trade will increase the GDP levels of the two involved countries are more comparable and when the geographical distance between them is smaller. Other variables were later added to the model, such as common language,

\footnotetext{
2 According to this model, factor abundance can be measured by either factor quantity (e.g.: number of machines relative to labor K/L) or factor relative price (e.g.: interest rate to wages ratio r/w) (see Salvatore 1999, pp. 115, 119).
} 
the comparative size of populations, access to the sea, common borders, and trade agreements (Bhattacharya and Wolde 2010, p. 9). Augmented forms of the gravity model further add other variables including institutional, governance, and economic factors (Martinez-Zarzoso et al. 2016, p. 11), making it a widely used model in the empirical literature on trade.

With reference to these augmented forms of the gravity model, governance institutions arguably provide a good explanatory framework. Governance could affect exporting, whether directly through trade regulations or indirectly through its impact on investment, innovation, and competitiveness. This should be true for the World Bank's identified governance institutions (the World Governance Indicators-WGI) of voice and accountability (V\&A), rule of law, regulatory quality, government effectiveness, and control of corruption. An important distinction that needs to be done is between indicators that directly affect trade- namely: regulatory quality and government effectiveness, and indicators that indirectly affect trade through creating better economic conditions, namely: V\&A, rule of law, and control of corruption.

The first category of governance indicators reflects the ability to formulate and implement policies and regulations that support exporting activities. Higher regulatory quality, for instance, will be reflected in implementing better trade-related regulations. This dimension is captured by the Doing Business (DB) "trading across borders" indicator, which is measured according to three components measuring the number of needed documents, amount of time, and cost (trade tariffs are excluded) to export and import. WB (2009, pp. 45-47) points to empirical studies showing how delays in exporting lead to significant losses. Moreover, it also argues that delays in importing can substantially hurt economies taking part in global supply chains. For participants in these chains, well-timed delivery of imported inputs is very crucial for domestic producers. Higher levels of government effectiveness, on the other hand, would be reflected in better formulation and implementation of export promotion strategies. Government effectiveness reflects the quality of the bureaucracy, its independence, and policy formulation and implementation.

Both regulatory quality and government effectiveness could also indirectly affect exporting. Higher regulation of entry, for instance, is believed to be detrimental to economic outcomes, since it affects competition, innovation, and productivity (see Djankov et al. 2002; Aghion et al. 2010; Beck 2005). Many empirical works showed such a negative relationship between higher regulation of entry and economic outcomes (see WB 2009, pp. 9-10; Djankov 2009; and Alesina et al. 2005). On the other hand, "Weberian bureaucracy", one which is coherent and recruited based on merit (Evans 1997), was found by Evans and Rauch (1999) to lead to better economic outcomes.

The indirect effect on exporting is also true for the three other considered governance indicators. Higher levels of V\&A would indicate higher government accountability to the public and a more open stance to freedom of association. Freedom of association, in its turn, would enable the growth of stronger business associations capable of aggregating and representing the interests of businesspeople. Smith (2004) argued that participatory and open policymaking processes improve the business climate by involving the people and making them keen on obtaining better outcomes. The expected resulting public support should intensify 
exchange, minimize the risk of investing, and improve government policy. This should lead to better trade policy formulation and implementation.

As for control of corruption, Anderson and Marcouiller (2002) found that corruption harms trade by increasing the insecurity of the done exchange. Moreover, many works in the literature pointed out the existence of a negative relationship between corruption and economic outcomes, due to augmenting business costs, distorting policies (Smith 2004), decreasing investment, misguiding government expenditure (Wei 1999), and reducing credit accessible to good business initiatives because of inefficient allocation of resources (Barth et al. 2009). Concerning the rule of law, Nunn (2007) has found that better contract enforcement provides a trade comparative advantage in relationship-specific investments. Empirically, many works showed that a positive correlation exists between protection of property rights and contract enforcement on one hand and economic development on the other (see Shirley 2005; and Glaeser et al. 2003). Clague et al. (1999) believed that government enforcement of contracts prevents the presence of serious impediments to the expansion of investment, innovation, and obtaining new technologies.

Nevertheless, the literature on developmental states and the experience of many East Asian countries shed many doubts on the suggested positive causality between good governance institutions and export performance. For instance, Kang (2003), while mainly referring to the East Asian export-led development experience, argued that cronyism (preferential treatment to connected businesspersons) can have a positive effect on economic growth. This is due to facilitating the enforcement of agreements, reducing monitoring costs, reinforcing integrity and credibility, and enabling better circulation of information. Such a positive relationship between corruption and growth is argued by Rock and Bonnett (2004) to be exclusive for the rising economies of East Asia, contrary to the experience of most developing countries. Gani and Scrimgeour (2016) found evidence that contract enforcement and Asian exports to Australia are negatively correlated.

Arguably, export-promoting strategies resting on supporting business cronies' exporting activities go hand in hand with preventing unconnected businesspeople from endangering those cronies' privileged access to resources. It, thus, means blocking broad-based independent activities through business associations (low V\&A), weak enforcement of rule of law, and strict market regulations to safeguard the cronies' market shares. An independent bureaucracy would not also be in line with this strategy. The more that this strategy affects efficiency the more it would be destructive to the export capabilities of the implementing country. Based on the above discussion, it could be argued that a crony-based export promoting strategy would be particularly inefficient if it suppressed aspects of governance that directly affect exporting. These were suggested here to be government effectiveness and regulatory quality. It would also be inefficient if important importers are so keen on promoting good governance and are using trade as a means to realizing this objective. Table 1 suggests that Germany could be a good example in this regard. 


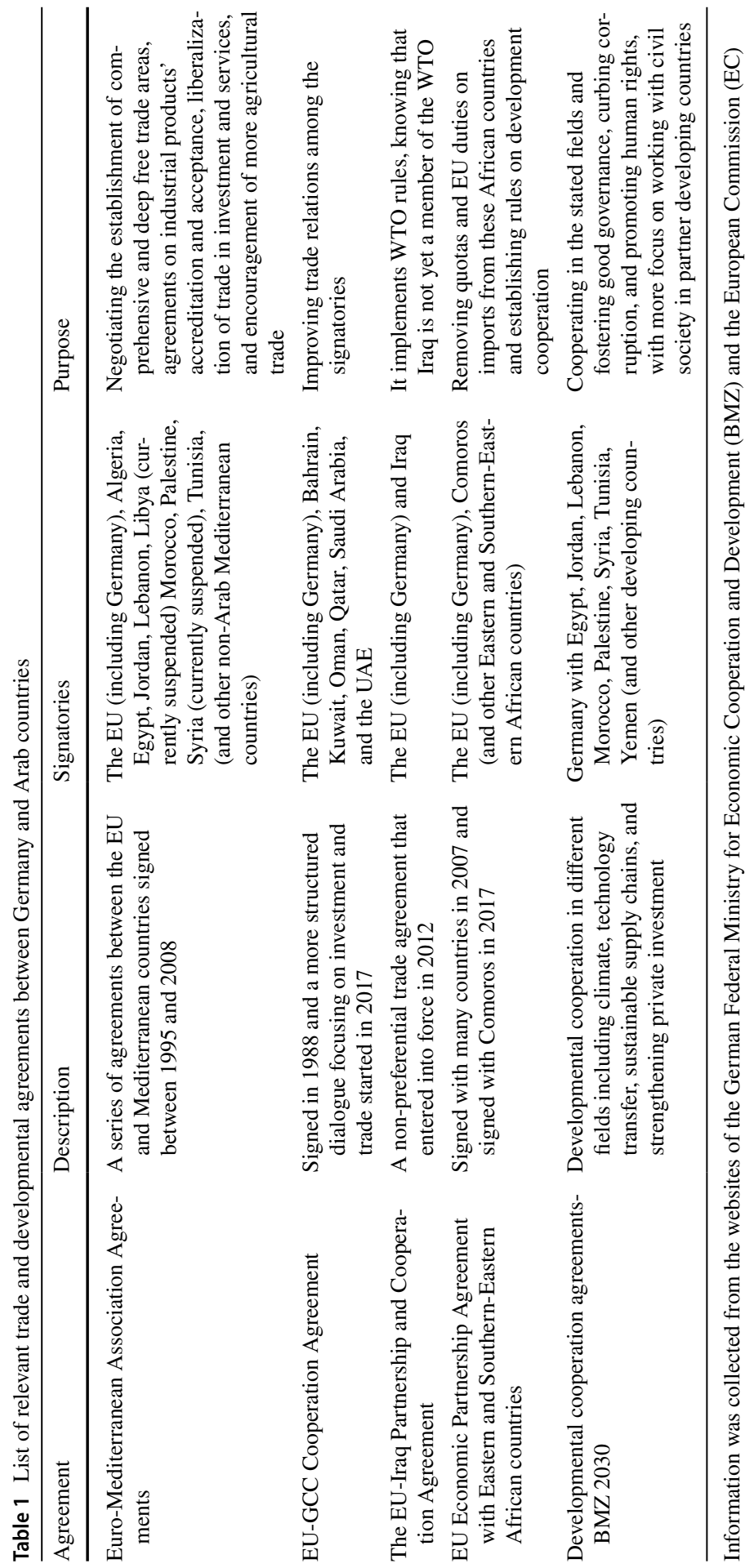




\section{The Case Study: Arab Exports to Germany}

\section{An Overview}

The purpose of this section is to investigate, with the help of statistical data, current Arab exporting activities to Germany from a comparative perspective.

Many trade and developmental agreements were signed between Germany (whether as a part of the EU or alone) and most of the Arab countries (see Table 1). This should have been translated into high levels of Arab exports to Germany, but the literature and statistical evidence suggest otherwise.

Generally speaking, many works pointed to the low export performance of the Middle East and North Africa (MENA) region (see Bhattacharya and Wolde 2010, p. 3). ${ }^{3}$ It has been estimated that the share of the Arab World of international exports of non-oil products stagnated at less than 1\% for three decades (Chauffour 2011, p. 2). Al-Atrash and Youssef (2000) found that Arab trade, whether intra-Arab or international, is below its potential as would be predicted by the gravity model. Another study by Behar and Freund (2011, pp. 4-5) found that MENA non-oil exports are below the world average. MENA exports to the world were estimated to be "only a third of their potential". Of more relevance to this study, Cieślik and Hagemejer (2009) found that MENA exports to Europe have not increased because of the EuroMediterranean free trade agreements, although MENA imports from Europe did increase. According to Ahmed (2010, p. 23), 60\% of Arab exports since the 1970s have flown to Europe. Nevertheless, German imports from the Arab world are lagging behind its imports from other regions of the world, as would be realized from looking at Table 2a (and Fig. S1 in Supplementary Appendix).

Table 2a shows German imports from different regions of the world. The classification used in Table $2 \mathrm{a}$ and other tables is different from the one used by the United Nations (UN) in some aspects. First, our suggested categories are mutually exclusive, where each country could only be placed in one category. Second, our used classification categorizes countries based on geographical and political-economic dimensions. The latter, which is relatively disregarded in the UN classification, accounts for trade agreements and blocks as well as political-economic relations between countries of the same category (NAFTA, Commonwealth of Independent States-former Soviet states etc.). Both points make our classification more relevant for our analysis than the UN classification. In Appendix 1, more details on the used classification are provided.

Table $2 \mathrm{~b}$ reports that, from a regional perspective, Arab countries stand in the fourth position as a destination for German exports, receiving around $3.37 \%$ of total German exports. It is preceded only by the EU, EU-Dependent, and Schengen countries (63\%), East Asia (11.34\%), and North America (10.61\%). German imports from the Arab region, however, are less significant. The region stands at the

\footnotetext{
3 The MENA region includes most of the Arab countries but excludes Arab Sub-Saharan countries such as Comoros, Djibouti, Mauritania, Somalia, and Sudan. It often includes instead non-Arab countries such as Iran, Israel and Malta.
} 
Table 2 Share of different world regions of German imports and exports in 2016

German imports from different world regions

\begin{tabular}{lcc}
\hline Partner & Share of German imports $(\%)$ & $\begin{array}{l}\text { Share of German imports } \\
\text { excluding oil imports }(*)\end{array}$ \\
\hline EU and EU-Dep/Scheng & 63.697 & 64.683 \\
East Asia & 16.82 & 18.12 \\
North America & 7.163 & 7.541 \\
Former Soviet & 3.535 & 0.949 \\
Balkan & 2.073 & 2.235 \\
Central and South Asia & 1.613 & 1.742 \\
South America & 1.457 & 1.4745 \\
Sub-Saharan Africa & 1.051 & 0.942 \\
Arab & 0.885 & 0.55 \\
Central America & 0.198 & 0.214 \\
Oceania & 0.091 & 0.099
\end{tabular}

German exports to different world regions

\begin{tabular}{ll}
\hline Partner & $\begin{array}{l}\text { Share of Ger- } \\
\text { man exports } \\
(\%)\end{array}$ \\
\hline EU and EU-Dep/Scheng & 63 \\
East Asia & 11.337 \\
North America & 10.61 \\
Arab & 3.372 \\
Former Soviet & 2.444 \\
Balkan & 2.237 \\
South America & 1.483 \\
Central and South Asia & 1.285 \\
Sub-Saharan Africa & 1.096 \\
Central America & 0.261 \\
Oceania & 0.111 \\
\hline
\end{tabular}

Source: Own calculation using data from Comtrade

9th position contributing by less than $0.9 \%$ of German imports and surpassing only Central America and Oceania (see Table 2a and Fig. S1 in Supplementary Appendix). Excluding oil (HS code 27), the share of German imports from Arab countries shrinks to only $0.55 \%$. Given the big weight of trading between Germany and EU, EU-Dependent and Schengen countries, looking at the share of the Arab region of extra EU, EU-Dependent, and Schengen German trade (after excluding trade with EU, EU-Dependent, and Schengen) is worthwhile. Total German imports from the Arab region amount to around 3\% in this case (see Fig. S2 in Supplementary Appendix). 
Looking at the trend followed by German trade with the Arab region, one can see that German exports to the region considerably and steadily grew between the years 2000 and 2008 from about $\$ 11$ billion to $\$ 41$ billion (see Fig. S3 in Supplementary Appendix). After a remarkable fall in 2009, it grew again reaching a new peak in 2014 at around $\$ 50$ billion, before shrinking once again in 2015, 2016, and 2017. German imports from the Arab region followed a slightly similar path, with imports growing between 2001 and 2008 from around \$7 billion to a peak of around \$21 billion. It also fell in 2009 before growing once again to around \$20 billion in 2013. Henceforth, the value of imports kept regressing steadily and dramatically, except for 2017 where it grew to $\$ 13$ billion. The share of oil imports from Arab countries represented $42.43 \%$ of total German imports from these countries (own calculation from Comtrade data for the year 2016). Regardless of their comparable trend movements, the gap between exports and imports considerably grew over time. In 1991, the gap was around $\$ 1.4$ billion (in favor of German exports). In 2017, the gap surpassed \$29 billion. As shares of German trade, a different image is provided by the data (see Fig. S4 in Supplementary Appendix). The gap between German exports to and imports from the Arab World kept fluctuating with a remarkable tendency to grow.

Such remarkable deterioration of the trade gap is explained neither by traditional trade theories nor by the gravity model unless governance indicators are accounted for as a factor affecting productivity and trade flows. The period witnessing the highlighted widening trade gap has coincided with a major deterioration in governance performance of Arab countries, as discussed later.

On an individual country basis, Table 3 shows that the United Arab Emirates (UAE) is the major Arab receiver of German exports. It ranks 20 globally. UAE is followed by: Saudi Arabia (32nd world rank); Egypt (40th); Qatar (51th); and Algeria (54th). Of more interest are the five major Arab countries in terms of contributing to German imports (major five Arab countries exporting to Germany). These are respectively: Tunisia (49th); Algeria (56th); Egypt (59th); Morocco (60th); and UAE (62nd). In other words, they are predominantly North African countries except for the UAE. Given the geographical proximity of North African countries to Germany, one could say that German importing behavior concerning the Arab world tends to follow the logic of the gravity model. If we excluded oil imports, Algeria would be no longer in the top five exporters and it would be replaced by Qatar.

Comparing the trading levels of individual Arab countries with Germany through time, the growth of German imports from the UAE between 1991 and 2016 is quite remarkable. The same applies to Egypt. However, more remarkable are the sharp decreases in imports coming from Saudi Arabia, Libya, and Algeria (see Fig. S5 in Supplementary Appendix). Again, such decreases in imports from Algeria and Libya could not be explained by the gravity model or traditional trade theories unless governance variables are accounted for.

The five main imported goods by Germany from the main five Arab exporters to the country are listed in Tables 4 and 5 (and shown in Fig. S6 in Supplementary Appendix). The most important goods are: 
Table 3 Share of different Arab countries of German imports in 2016

\begin{tabular}{|c|c|c|c|c|c|}
\hline Partner & $\begin{array}{l}\text { Total German } \\
\text { import value (in } \\
\text { Billion US\$) }\end{array}$ & $\begin{array}{l}\text { Share of } \\
\text { total German } \\
\text { imports }(\%)\end{array}$ & $\begin{array}{l}\text { Share of } \\
\text { total German } \\
\text { imports, } \\
\text { excluding } \\
\text { imports } \\
\text { from the EU, } \\
\text { EU-Dep., and } \\
\text { Schengen } \\
\text { States (\%) }\end{array}$ & $\begin{array}{l}\text { Share of } \\
\text { total Ger- } \\
\text { man imports, } \\
\text { excluding oil } \\
\text { imports (\%) }\end{array}$ & $\begin{array}{l}\text { World rank } \\
\text { (as exporter to } \\
\text { Germany) }\end{array}$ \\
\hline Tunisia & 1.801 & 0.170 & 0.468 & 0.168 & 49 \\
\hline Algeria & 1.467 & 0.138 & 0.381 & 0.008 & 56 \\
\hline Egypt & 1.255 & 0.118 & 0.326 & 0.069 & 59 \\
\hline Morocco & 1.165 & 0.110 & 0.303 & - & 60 \\
\hline UAE & 1.018 & 0.096 & 0.264 & 0.102 & 62 \\
\hline Saudi Arabia & 0.701 & 0.066 & 0.182 & 0.041 & 66 \\
\hline Iraq & 0.646 & 0.061 & 0.168 & $4.36 \mathrm{e}-04$ & 69 \\
\hline Libya & 0.616 & 0.058 & 0.160 & 0.001 & 71 \\
\hline Qatar & 0.420 & 0.040 & 0.109 & 0.013 & 77 \\
\hline Mauritania & 0.064 & 0.006 & 0.017 & - & 114 \\
\hline Lebanon & 0.058 & 0.005 & 0.015 & - & 116 \\
\hline Oman & 0.044 & 0.004 & 0.011 & - & 120 \\
\hline Bahrain & 0.033 & 0.003 & 0.009 & 0.003 & 126 \\
\hline Jordan & 0.027 & 0.003 & 0.007 & - & 129 \\
\hline Kuwait & 0.021 & 0.002 & 0.006 & 0.002 & 133 \\
\hline Sudan & 0.018 & 0.002 & 0.005 & - & 136 \\
\hline Syria & 0.017 & 0.002 & 0.004 & - & 139 \\
\hline Comoros & 0.006 & 0.001 & 0.001 & - & 152 \\
\hline Yemen & 0.003 & 0.000 & 0.001 & - & 167 \\
\hline Somalia & 0.001 & 0.000 & 0.000 & - & 178 \\
\hline Djibouti & 0.001 & 0.000 & 0.000 & - & 181 \\
\hline Palestine & 0.001 & 0.000 & 0.000 & - & 184 \\
\hline
\end{tabular}

Source: Own calculation using data from Comtrade

- "Electrical machinery and equipment and parts thereof, sound recorders and reproducers, television image and sound recorders and reproducers parts and accessories of such articles" (Code 85): is a major imported good for Germany from four of these five countries: Egypt (4.5\% of German total imports from Egypt); Morocco (15.36\%); Tunisia (46.91\%); and the United Arab Emirates $(6.91 \%)$.

- "Mineral fuels mineral oils and products of their distillation, bituminous substances mineral waxes"(Code 27): is a major import of three out of the five countries: Algeria (94.81\%); Egypt (45.78\%); and Tunisia (8.64\%). 
Table 4 Major exported goods of the major five Arab exporters to Germany in 2016

\begin{tabular}{|c|c|c|c|c|c|}
\hline Import partner & Commodity & $\begin{array}{l}\text { Share of total } \\
\text { imports from this } \\
\text { country }(\%)\end{array}$ & Import partner & Commodity & $\begin{array}{l}\text { Share of total } \\
\text { imports from this } \\
\text { country }(\%)\end{array}$ \\
\hline \multirow[t]{5}{*}{ Algeria } & HS Code 27 & 94.81 & \multirow[t]{5}{*}{ Egypt } & HS Code 27 & 45.78 \\
\hline & HS code 28 & 2.09 & & HS Code 07 & 6.15 \\
\hline & HS Code 31 & 1.87 & & HS Code 61 & 5.09 \\
\hline & HS Code 26 & 0.28 & & HS Code 08 & 4.8 \\
\hline & HS Code 99 & 0.27 & & HS Code 85 & 4.5 \\
\hline \multirow[t]{5}{*}{ Morocco } & HS Code 62 & 16.16 & \multirow[t]{5}{*}{ Tunisia } & HS Code 85 & 46.91 \\
\hline & HS Code 85 & 15.36 & & HS Code 62 & 20.33 \\
\hline & HS Code 61 & 13.74 & & HS Code 27 & 8.64 \\
\hline & HS Code 64 & 12.26 & & HS Code 64 & 7.35 \\
\hline & HS Code 07 & 10.04 & & HS Code 61 & 3.52 \\
\hline \multirow{5}{*}{$\begin{array}{l}\text { United Arab Emir- } \\
\text { ates }\end{array}$} & HS Code 76 & 47.77 & & & \\
\hline & HS Code 88 & 8.93 & & & \\
\hline & HS Code 99 & 8 & & & \\
\hline & HS Code 85 & 6.91 & & & \\
\hline & HS Code 39 & 4.03 & & & \\
\hline
\end{tabular}

Description of Codes:

HS Code 07: Vegetables and certain roots and tubers edible

HS Code 08: Fruit and nuts edible peel of citrus fruit or melons"

HS Code 26: Ores slag and ash

HS code 27: Mineral fuels mineral oils and products of their distillation "bituminous substances mineral waxes"

HS Code 28: Inorganic chemicals organic and inorganic compounds of precious metals of rare earth metals of radio-active elements and of isotopes

HS Code 31: Fertilizers

HS Code 39: Plastics and articles thereof

HS Code 61: Apparel and clothing accessories knitted or crocheted

HS Code 62: Apparel and clothing accessories not knitted or crocheted

HS Code 64: Footwear gaiters and the like parts of such articles

HS Code 76: Aluminum and articles thereof

HS Code 85: Electrical machinery and equipment and parts thereof sound recorders and reproducers

television image and sound recorders and reproducers parts and accessories of such articles"

HS Code 88: Aircraft spacecraft and parts thereof

HS Code 99: Commodities not specified according to kind

Source: Own calculation using data from Comtrade

- "Vegetables and certain roots and tubers edible" (Code 7): is among the leading imports that originate from Egypt (6.15\% of total imports from Egypt) and Morocco (10.04\%).

- "Apparel and clothing accessories knitted or crocheted" (Code 61): is a major import from Egypt (5.09\%) and Morocco (13.74\%).

- "Apparel and clothing accessories, not knitted or crocheted" (Code 62): is a major import from Morocco (16.16\%) and Tunisia (20.33\%). 
Table 5 Average volume and share of German commodity imports from the leading five Arab exporting countries

\begin{tabular}{lllc}
\hline Commodity code & Commodity (short description) & $\begin{array}{l}\text { Average imports } \\
\text { trade value (US\$) }\end{array}$ & Average share (\%) \\
\hline HS Code 27 & Mineral Fuels & $533,372,483.8$ & 37.62 \\
HS Code 85 & Electrical machinery and equipment & $230,157,871.6$ & 14.74 \\
HS Code 76 & Aluminum & $107,901,009.8$ & 10.38 \\
HS Code 62 & Apparel (not knitted or crocheted) & $149,055,635.8$ & 9.97 \\
HS Code 64 & Footwear gaiters & $68,983,751.5$ & 4.92 \\
HS Code 61 & Apparel (knitted or crocheted) & $58,968,066.4$ & 4.62 \\
HS Code 07 & Vegetables & $50,114,093.5$ & 4.14 \\
HS Code 08) & Fruit and nuts & $29,291,298.0$ & 2.28 \\
\hline
\end{tabular}

Source: Own calculation using data from Comtrade

- "Footwear gaiters and the like parts of such articles" (Code 64): from Morocco $(12.26 \%)$ and Tunisia $(7.35 \%)$.

Some of the mentioned goods imported by Germany from Arab countries match the theoretical expectations of the Heckscher-Ohlin model given their labor-intensive nature in labor-abundant Arab countries. This is the case, for instance, for agricultural products such as codes 7 and 8, and light industries related to the textiles sector such as codes 61 and 62 . However, code 39 for plastics and code 85 for electrical machinery and equipment contradicts this theoretical perspective.

\section{Good Governance as an Explanatory Factor}

Could the performance of Arab countries in various governance indicators have a significant effect on their export performance to Germany? The previous theoretical and statistical sections suggested that this could be possible, but an empirical investigation is still needed.

The literature on Arab countries seems to suggest that institutions (see Méon and Sekkat 2004) and especially governance institutions (see Karam and Zaki 2019 and Martinez-Zarzoso et al. 2016) do harm the region's general export performance. Martinez-Zarzoso et al. (2016) found that governance indicators significantly affect the regions' exports and imports. All the six governance indicators, except for regulatory quality, affected MENA exports positively; and, in a comparative sense, their effects were bigger than for exports from the rest of the world. The Arab Spring has been responsible for shifting more emphasis on V\&A as a factor boosting the MENA region's exports.

Statistically, the poor export performance of the Arab region correlates with its bad performance in the governance indicators. As Table 6 (and Fig. S7 in Supplementary Appendix) shows, the Arab average percentile rank in 2010 and 2015 is always below the 40 percentile in all studied governance indicators (V\&A does not 
Table 6 Average Arab performance in governance indicators

\begin{tabular}{llcc}
\hline & & Arab avg & Arab avg \\
& & Year & \\
\cline { 2 - 3 } & & 2010 & 2015 \\
\hline Control of corruption & Estimate & -0.39 & -0.54 \\
& Percentile Rank & 39.83 & 35.14 \\
Government effectiveness & Estimate & -0.44 & -0.56 \\
Political stability and absence of violence/ & Estimate & 39.00 & 34.62 \\
terrorism & Percentile Rank & -0.77 & -1.06 \\
Regulatory quality & Estimate & 30.72 & 23.81 \\
& Percentile Rank & -0.39 & -0.54 \\
Rule of law & Estimate & 39.00 & 35.49 \\
Voice and accountability (V\&A) & Percentile Rank & -0.40 & -0.52 \\
& Estimate & 39.68 & 35.95 \\
& Percentile Rank & -1.12 & -1.08 \\
\hline
\end{tabular}

Source: Own calculations using data from the World Bank Worldwide Governance Indicators (WGI)

even reach the 20 percentile rank). A clear deterioration is even witnessed between the two years for most of the studied governance indicators.

The region's unfavorable regulatory quality is reflected in "high and complex tariffs" (see Behar and Freund 2011, p. 4), which is anticipated to hinder the region's integration into "production sharing" and "processing-type of trade" (Chauffour 2011, p. 13). Non-tariff measures (NTMs) are even a bigger obstacle for Arab trade (Chauffour 2011, pp. 13-14). This includes "excessive delays" attributed to long processes of inspection and clearance, the various needed documents and signatures for every trade transaction, and frequent problems encountered with state authorities. Bhattacharya and Wolde (2010, p. 16) found empirical evidence that "efficiency of customs clearance" explained why the region underperforms in trade. Having a poor business climate was held responsible for the unsatisfactory exporting performance of the MENA region, either through its unfavorable effect on competitiveness (Ahmed 2010) or SME startups (Nabli 2007a,b, and Bhattacharya and Wolde 2010, p. 6).

The low levels of control of corruption and V\&A support the usual arguments made in the literature on state-business relations (SBR) in the region. This literature points to the dominance of informal forms of SBR (relations based on social and political relations) and cronyism as well as the weakness of formal SBR (e.g.: public-private dialogues) and broad-based business associations' lobbying (see Sabry 2018; Hertog 2013; Nabli 2007b). As suggested by the theoretical section of this paper, such SBR typology should have its effect on the economic performance of the region, including its export performance. The same applies with regard to the weak performance of the region in the rule of law and government effectiveness indicators. 
The previous discussion suggests that, for economic reasons, a higher performance of Arab countries in the governance indicators should increase their exports to Germany. Yet, additional reasons are supporting this assumption. An important one is specific to German developmental policy objectives. The EU proclaims the adoption of a "developmental friendly" trade policy, where its generalized scheme of preferences-plus (GSP) ${ }^{+}$offers high reductions of tariffs on exports from developing countries provided that they abide by good governance (among others) principles (see BMZ, Global Trade). This is added to the German developmental cooperation commitment, stated in the BMZ 2030 Reform Strategy, to induce partner developing countries to fight corruption and involve their civil society. Strong business associations supported by higher levels of V\&A should help in realizing such a developmental objective. Hence, a good performance particularly in control of corruption and V\&A should be expected to boost chances of exporting to Germany.

\section{Methodology}

In this section, an empirical investigation using regression analysis is conducted to tackle the research question. We start with a discussion on which regression model should be used.

It is common in studies on trade relations to use OLS regressions with the specifications of the gravity model. Three major concerns, however, arise. The first is about zero trade flows that would make the use of OLS estimators inconsistent when using the logarithmic transformation of the dependent variables (see Yotov et al. 2016). Luckily, despite having many missing data, the used dataset, Comtrade, does not report any zero trade flows in the dependent variables of interest. The second concern is on the possible endogeneity of institutions (see Karam and Zaki 2019). This calls for the use of the two-stage least squares (TSLS) model. The final concern is about heteroskedasticity that usually characterizes the data on trade (Yotov et al. 2016). The results of the White's test have shown that heteroscedasticity might be of concern (see Table 13 in Appendix 2). Santos Silva and Tenreyro (2006) suggested the use of the Poisson pseudo maximum likelihood (PPML) regression model to address this concern (see Yotov et al. 2016). We assume that addressing the endogeneity concern takes precedence over addressing heteroscedasticity. Accordingly, the results of the TSLS are used in the following analysis, while those of the PPML model are used to test for the robustness of the obtained results. ${ }^{4}$ The regressions conducted by the TSLS and PPML models are reported in Appendix 2.

\footnotetext{
4 The fixed effects and random effects models are usually of less help when the studied variables have little time invariability. This is more likely the case with governance indicators and even more for important but invariant control variables such as the EU dummy and (the log of) weighted distance. Excluding the EU dummy variable will make the results for non-Arab countries account for EU countries with their massive weight on German imports and their higher governance scores. That is why these two models are not considered here.
} 
The conducted regressions cover the period between 1990 and 2017, are done on a global scale, and have different specifications. The most general form is the following:

$$
\begin{aligned}
& (\operatorname{Im~})_{\mathrm{Gi}}=\alpha+\beta_{1}(\text { Arab })_{\mathrm{i}}+\beta_{2}(\text { Governance })_{\mathrm{i}}+\beta_{3}(\text { Arab })_{\mathrm{i}}(\text { Governance })_{\mathrm{i}} \\
& +\beta_{4}(\text { Control Variables })
\end{aligned}
$$

Four sets of regressions are conducted, each of which with a different dependent variable. The dependent variable in Set $\{A\}$ Regressions is German imports $(G)$ from country (i) and in sets $\{B\},\{C\}$, and $\{D\}$ regressions the dependent variable is German imports from country (i) of codes 85, 61, and 62 respectively. These products were suggested earlier to be among the major non-oil industrial exports of Arab countries to Germany. The used control variables are inspired by the gravity model and other variables specific to the German case. Thus, the weighted distance between Germany and a studied country and the differences in population sizes and GDP per capita (both in absolute terms) are used as control variables. Another control variable is the EU dummy, which is used to account for the special trading position of the EU with Germany. Moreover, since we are more interested in non-oil exports of Arab countries (German imports from Arab countries), two additional control variables are used. The first is the German fuel imports (code 27) and the other is the interaction of this variable with the Arab dummy. These two variables are, however, excluded in regression sets B, C, and D.

As conventional in gravity model regressions, the regressions conducted by TSLS use the logs of the highlighted dependent variables as well as logs of the weighted distance, population differences, GDP per capita differences, and German fuel imports. Regressions conducted by PPML, however, use level values of the mentioned variables, as suggested by (Yotov et al. 2016). For the TSLS regressions, several instruments are used. These are variables on legal origins (British, French, and German, excluding Scandinavian to avoid multicollinearity), percentage of adherents to various religions (Catholic, Protestant, Orthodox, Muslim, and Buddhist), ethnic fractionalization, and colonial heritage. The data is obtained from Sabry (2013), which in its turn collected and refined data from different sources. ${ }^{5}$

The variables of interest are: the Arab dummy; the performance of an exporting country in the five governance indicators of V\&A, government effectiveness, regulatory quality, rule of law, and control of corruption; and the interaction between each of these governance indicators and the Arab dummy.

Running the variance inflation factors (VIF) test has shown that the concern that is often suggested in the literature (see Karam and Zaki 2019) on the presence of multicollinearity between the different considered governance indicators is justified (see Table 14 in Appendix 2). Thus, the above-mentioned five governance indicators are introduced simultaneously to the regressions. Thus, in every conducted set of

\footnotetext{
${ }^{5}$ For data on legal origins: La Porta et al. (2008); for data on religion adherents: the UN "Ethno-culture characteristics", CIA Factbook, and the "Association of Religion Data Archives" (ARDA); for data on ethnic fractionalization: the Quality of Government Dataset and Alesina et al. (2003); and for colonial heritage: Acemoglu et al. (2001).
} 
Table 7 Summary statistics

\begin{tabular}{lrrrrrrr}
\hline Variable & Mean & Median & \multicolumn{1}{l}{ Min } & Max & Std. Dev & Skew & Ex. Kurtosis \\
\hline Arab & 0.10 & 0.00 & 0.00 & 1.00 & 0.30 & 2.62 & 4.89 \\
EU & 0.16 & 0.00 & 0.00 & 1.00 & 0.36 & 1.87 & 1.51 \\
Log German imports & 18.13 & 18.38 & 3.50 & 25.49 & 3.70 & -0.37 & -0.23 \\
Ctrl. Corrupt & 49.87 & 44.97 & 8.85 & 101.71 & 20.03 & 0.62 & -0.45 \\
Gov. Effect & 49.85 & 46.65 & 0.26 & 98.63 & 20.02 & 0.33 & -0.68 \\
Reg. Qual & 49.85 & 47.70 & -3.51 & 95.26 & 20.00 & 0.02 & -0.68 \\
Rule of Law & 49.78 & 46.85 & -3.38 & 92.41 & 19.93 & 0.21 & -0.87 \\
V\&A & 49.83 & 50.21 & 4.28 & 86.53 & 20.00 & -0.19 & -1.01 \\
Arab*Ctrl. Corrupt & 2.46 & 0.00 & 0.00 & 84.46 & 10.48 & 4.51 & 20.36 \\
Arab*Gov. Effect & 2.36 & 0.00 & 0.00 & 80.74 & 10.27 & 4.57 & 20.61 \\
Arab*Reg. Qual & 2.36 & 0.00 & -3.29 & 72.67 & 10.28 & 4.52 & 19.86 \\
Arab*Rule of Law & 2.44 & 0.00 & -3.38 & 71.07 & 10.54 & 4.47 & 19.34 \\
Arab*V\&A & 1.71 & 0.00 & 0.00 & 53.84 & 7.26 & 4.33 & 17.93 \\
Log Pop. Difference & 18.02 & 18.15 & 12.27 & 20.99 & 0.57 & -1.57 & 18.68 \\
Log weighted distance (distw) & 8.47 & 8.75 & 5.71 & 9.81 & 0.89 & -1.04 & 0.33 \\
Log GDP Diff. per capita & 9.96 & 10.30 & 1.73 & 11.43 & 0.95 & -3.02 & 12.19 \\
Log Code85 G. Imports & 14.01 & 13.05 & 0.00 & 24.26 & 4.64 & 0.31 & -1.02 \\
Log Code62 G. Imports & 14.08 & 14.78 & 3.50 & 22.65 & 4.30 & -0.23 & -1.13 \\
Log Code 61 G. Imports & 14.24 & 14.74 & 1.61 & 22.40 & 4.13 & -0.41 & -0.82 \\
Log Code27 G. Imports & 16.95 & 17.60 & 0.00 & 24.59 & 3.78 & -0.81 & 0.35 \\
Arab*log Code27 G. Imports & 0.81 & 0.00 & 0.00 & 22.82 & 3.82 & 4.64 & 19.97 \\
\hline & & & & & & & \\
\hline
\end{tabular}

regressions (A, B, C, and D), five different regressions are conducted each having a different governance indicator among the dependent variables and a sixth regression having the average of the studied five governance indicators.

German total imports and its imports of different products are obtained from the United Nations Comtrade dataset. The weighted distance variable, which is used to measure distances between Germany and the studied countries, is obtained from the dataset of the "Centre d'Etude Prospectives et d'Informations Internatinales" (CEPII) GeoDist dataset (the distw indicator, see Mayer and Zignago 2011, p. 11). The governance indicators are obtained from the worldwide governance indicators (WGI) dataset. To facilitate the analysis done in the following section, the governance indicators are rescaled to a percentage scale running from 0 to 100 in ascending order (instead of the original order running between -2.5 and +2.5 ). Population and GDP per capita figures are obtained from the World Bank's world development indicators (WDI) dataset. Finally, the Arab and EU dummies are created from the available data as explained in the theoretical section. Descriptive statistics of the used variables are reported in Table 7 and the results obtained from the various regressions using the TSLS model and PPML models are reported in Appendix a.

To facilitate the analysis done in the next section, calculating the effect of various governance variables on different dependent variables is calculated for Arab countries and non-Arab countries. This is done as follows: 
Table 8 The effect of a $0.01 \%$ increase in Governance indicators on German imports (using TSLS model)

\begin{tabular}{llllllll}
\hline & & V\&A & C. Corrupt & Gov. Eff & R. Law & Reg. Qual & Avg. Gov \\
\hline German Imports (log) & Arab & 1.312 & 1.278 & 0.852 & 1.011 & 1.337 & 1.202 \\
& Non-Arab & 0.125 & 0.053 & $\mathbf{0 . 0 6 2}$ & $\mathbf{0 . 0 6 0}$ & $\mathbf{0 . 0 7 2}$ & $\mathbf{0 . 0 7 0}$ \\
Code 85 German Imports & Arab & -0.897 & - & 2.288 & 1.692 & 2.989 & - \\
$(\log )$ & Non-Arab & 0.063 & 0.040 & - & $\mathbf{0 . 0 5 9}$ & - & - \\
Code 61 German Imports & Arab & -0.545 & - & 3.579 & 1.431 & 3.334 & - \\
$(\log )$ & Non-Arab & $\mathbf{- 0 . 0 3 2}$ & - & - & - & - & - \\
Code 62 German Imports & Arab & -0.689 & - & $\mathbf{2 . 8 9 0}$ & 1.792 & 4.109 & - \\
$(\log )$ & Non-Arab & $\mathbf{- 0 . 0 6 5}$ & $\mathbf{- 0 . 0 2 5}$ & - & - & - & - \\
\hline
\end{tabular}

The reported values are obtained from the TSLS model. The values written in the bold script are the values having the same sign and are statistically significant in both the TSLS and PPML regressions. In Italic script are the values having the same sign in both models but are statistically significant in TSLS and insignificant in PPML regressions

For the function: $Y=\beta_{0}+\beta_{1} \operatorname{Gov}_{j}+\beta_{2}\left(\operatorname{Gov}_{j} \times A r a b\right)$, where $\operatorname{Gov}_{\mathrm{j}}$ is a governance indicator in country $(j)$.

- When an exporting country is Arab:

$$
\text { Overall Effect of Gov on } Y=\beta_{1}+\beta_{2}(1)=\beta_{1}+\beta_{2}
$$

- When an exporting Country is non-Arab:

$$
\text { Overall Effect of } \mathrm{Gov}_{j} \text { on } Y=\beta_{1}+\beta_{2}(0)=\beta_{1}
$$

The results obtained by using these equations are reported in Table 8 . Only statistically significant variables are used in calculating these results. The reported figures are calculated from the TSLS regressions. The figures written in the bold and Italic scripts are the ones whose signs are confirmed by the regressions conducted by the PPML model. The figures written in the bold script are both matching in sign and statistically significant using both regression models. The figures are written in Italic, however, are matching in sign but are statistically significant in the TSLS regressions and insignificant in the PPML ones. Given the use of logs for the dependent variables in all the conducted regressions, the magnitude of the effects of the governance indicators is showing the effect of an increase of $0.01 \%$ in these indicators on the dependent variables. 


\section{Results and Discussion}

The results of the TSLS regressions (reported in Table 11 in Appendix 2) show that concerns on endogeneity, and specifically reverse causality, were justified. The Hausmann test shows that for most conducted regressions OLS is inconsistent and TSLS is preferred.

The results of the TSLS model regressions mostly show the expected signs for the used control variables. The logs of weighted distance, population differences, GDP per capita differences have mostly a negative effect on the different studied dependent variables, while the EU dummy has a positive effect. These coefficients of the four control variables, however, have sometimes unexpected signs and are often statistically insignificant.

Using Table 8, all the considered governance indicators of the exporting countries, whether Arab or non-Arab, have a positive and statistically significant effect on German imports. The effect is comparatively stronger for Arab countries (in comparison to non-Arab countries) for every indicator. Among the considered six governance variables, the strongest effect for Arab countries on German imports is caused by regulatory quality followed by V\&A then Control of Corruption, average governance, rule of law, and finally government effectiveness. For nonArab countries, the corresponding order is V\&A, regulatory quality, average governance, government effectiveness, rule of law, and control of corruption.

This straightforward positive relation between exporting countries' governance indicators and German imports from these countries is less evident for the studied specific products. Generally speaking, the various governance indicators seem to affect German imports from Arab countries more than they do for non-Arab countries. For non-Arab countries, only V\&A, rule of law, and control of corruption have a positive effect on German imports of code 85 products. Codes 61 and 62 imports seem not to be boosted by better governance performance of exporting non-Arab countries. For Arab countries, however, three governance indicators positively affect German imports of the studied three codes' products (codes 85, 61, and 62). Ranked according to the strength of their effect, these are: regulatory quality (strongest effect on codes 85 and 62 and second strongest on code 61 imports); government effectiveness (strongest effect on code 61 and the second strongest on codes 85 and 62 imports); and rule of law.

Surprisingly, V\&A of the exporting countries, whether Arab or non-Arab, has a negative effect on German imports of the three studied products. The only exception is the positive effect of V\&A of non-Arab countries on German imports of code 85 products. The negative effect of this governance indicator on imports of the three products is stronger for Arab countries than for non-Arab countries, standing in contrast to the effect of the indicator on overall German imports. Another indicator that has a negative effect on imports is control of corruption, but the effect is only on code 62 imports and only for non-Arab countries.

Using the results of the PPML regressions as a robustness check (see Table 12 in Appendix 2), only a few of the results reported in Table 8 have the sign of their effect confirmed and are statistically significant (the results written in bold 
script). These results are predominantly representing the effects of different governance indicators on imports from non-Arab countries. For non-Arab countries, both the TSLS and PPML regressions yield the same sign of the effect of government effectiveness, rule of law, regulatory quality, and average governance on total German imports (positive effect), rule of law on code 85 imports (positive effect), control of corruption on code 62 imports (negative effect), and V\&A on codes 61 and 62 imports (negative effect). For Arab countries, only the positive effect of government effectiveness on code 62 imports is confirmed. The results yielding the same sign for both regression models but which are only statistically significant in the TSLS regressions (written in Italic) are the positive effect of Arab countries' V\&A, control of corruption, government effectiveness, and average governance on German total imports, as well as government effectiveness on code 85 German imports.

The results, thus, suggest that the two governance indicators that are more directly related to exporting activities- that is to say, regulatory quality and government effectiveness- are responsible for increasing different countries' exports to Germany. The same applies to rule of law which indirectly affects exporting activities. This is true for Arab and non-Arab countries with regard to German total imports, and true for Arab countries in the studied three non-oil industrial products that are among the most remarkable Arab exports to Germany. Better performance in these three governance indicators is crucial for the exporting activity of Arab countries to Germany both in absolute terms and in a comparative sense relative to non-Arab exporting countries. The positive effect of government effectiveness and regulatory quality, in both Arab and non-Arab countries, is matching the theoretical reasoning introduced earlier in this paper. Better export performance should be realized from having a better-equipped and independent bureaucracy that is more capable of formulating and implementing export-promoting policies and regulations. The same is true for rule of law that should indirectly foster exporting by encouraging investment.

For V\&A and control of corruption, the results are, however, mixed. These are the two governance indicators that, arguably, are relatively lesser connected to efficiency and (mostly) indirectly affecting exporting. However, they are the most related governance indicators to German trade and developmental policy (as stated in the BMZ 2030 Reform Strategy). While both indicators have a positive effect on exporting in terms of their effect on German total imports, V\&A seems to have a negative effect on exporting to Germany for the textile industry (codes 61 and 62) whether from Arab or non-Arab countries. Counter-intuitively, V\&A also negatively affects Arab countries' exports to Germany of the more sophisticated code 85 product. Control of corruption, on the other hand, seems to negatively affect non-Arab countries' exports of code 62 to Germany. Such results raise doubts on the German proclaimed commitment to fostering good governance and the possibility that it directs its trading policies towards this objective, knowing that these two governance indicators are at the core of this commitment. Thus, this seems to discredit German developmental (pro-governance promotion) trade policy as a possible explanatory factor, especially with regard to the textile industry.

For non-Arab exporters to Germany, these results could be attributed to the East Asian model of crony capitalism, characterized by high cronyism and corruption 
(especially after excluding the effect of EU countries on German imports). It might suggest how government crony privileges in the textile industry enable connected businesspersons to be more export competitive at the expense of the non-connected who are denied much independent lobbying power. For Arab countries, lower V\&A is more relevant while crony privileges do not seem to foster exports from this industry. The Arab exporters in this industry seem to benefit from the restrictions put on independent lobbying of non-connected businesspeople; but it is also possible that they benefit from hindering any opposing societal independent action, with labor union activism being a possible candidate. Nevertheless, putting things into perspective, it was suggested earlier that the Arab World suffers from a poor export performance that is lower than the region's potential. The connected and privileged who are shielded from opposing societal activities could have more access to German markets in this industry. But this does not mean that they are the most efficient and the export performance of Arab countries might have been better with higher V\&A.

\section{Conclusion}

This paper investigated the effect of good governance indicators on Arab countries' exports to Germany, which is a leading world economy, a country bound by trade agreements with the countries of the region, and one which is committed to promoting good governance. The theoretical discussion suggested the presence of such a link between the region's governance institutions and its export performance, widely claimed in the literature to be rather below potential. The link flows directly through the effect of factors such as regulatory quality on export performance as well as indirectly through the effect of most of the governance indicators on private investment, innovation, and competitiveness.

The implications of the obtained empirical results were double-folded. On one hand, governance indicators are generally suggested to foster Arab exports to Germany even more than they do to non-Arab countries' exports to Germany. This is especially true for governance indicators that are more directly related to export activities, such as government effectiveness and regulatory quality, but also for rule of law. This is evident in the effect of these indicators on total exports to Germany and exports of the three studied products (codes 61, 62, and 85). On the other hand, the results raised doubts on German commitment to promoting good governance, especially concerning the countries from which it imports textiles, an industry that is of much importance to many developing countries.

This research, thus, suggests that Arab countries should conduct major institutional reform and especially in the fields of government effectiveness, regulatory quality, and rule of law. That does not mean disregarding the need for a major reform in V\&A where the region's performance is very poor. Government effectiveness and regulatory quality should benefit tremendously from more government engagement in policy consultation with broad-based business associations as partners in formal SBR. Furthermore, improving accountability and fostering formal state-business consultation would diminish the need for informal SBR and crony networks as means for encouraging investment and general economic activity. This could consequently turn the efforts 
for controlling corruption and improving regulatory quality into favorable endeavors that would yield better economic outcomes and foster export competitiveness. On the other hand, Germany should keep up to its developmental goals and provide incentives for the better application of good governance principles especially in sectors that are of much importance for developing countries.

Despite the useful insights provided by this research, we have to point to its limitations. These are mainly data-related limitations and match the general comment on the literature on the Arab world. A more detailed dataset having information on the channels through which various governance indicators affect Arab exports to Germany would be a breakthrough in investigating the topic. For instance, information on business associations, their interactions with the state in public-private dialogues, and the effectiveness of such a mechanism would have helped in precisely identifying which components of voice and accountability are responsible for the region's performance. The same is also true for the rest of the studied governance indicators. Nevertheless, rather than providing conclusive evidence on the issue, the purpose of this paper is to open a discussion and invite research on these aspects. We hope that the collection of more detailed data on many Arab countries and even on the sectoral level inside each country could help future research and further investigation of this important topic.

\section{Appendix 1: The Used Classification in Comparison to the UN Classification}

As mentioned in the main text, the categorization used in this paper is different than the one used by the UN. First, the used categories are mutually exclusive, where a country can not be placed in two different categories. Second, our used classification groups countries together based on geographical and political-economic concerns.

For instance, the UN classification places the heterogeneous regions of East and West Europe and Central Asia together. Instead, our classification devotes a category for the EU and all the countries having largely similar economic treatment to EU countries, such as small autonomous states within the borders of EU countries (e.g.: Vatican and Andorra) and Schengen non-EU states (e.g.: Switzerland and Norway). Former Soviet Union countries (other than EU Baltic states) are placed together in another category. The Eastern European non-EU countries concentrated in the geographical region of the Balkan are placed together in a category referring to the region (i.e.: Balkan). Since the constructed categories are mutually exclusive, Arab countries such as Sudan, Mauritania, and Somalia are not included in the SubSaharan category. The non-Arab MENA country of Iran is placed in the category of Central and South Asia. Central America is distinctive economically from South America and, thus, each is placed in a different category. North America is bound together by the NAFTA and Mexico is part of this trade block, making it more reasonable to place it with North America rather than the UN category of Latin America. Finally, the two distinctive groups of countries of East Asia and Pacific placed together in the UN classification are separated here into the two categories of "East Asia" and "Oceania" (Tables 9 and 10). 
Table 9 Own categorization of countries

\begin{tabular}{|c|c|}
\hline Region & Countries \\
\hline Arab & $\begin{array}{l}\text { Algeria; Bahrain; Comoros; Djibouti; Egypt; Iraq; Jordan; Kuwait; } \\
\text { Lebanon; Libya; Mauritania; Morocco; Oman; Qatar; Saudi Arabia; } \\
\text { Somalia; Sudan; Syria; Tunisia; United Arab Emirates (UAE); Pales- } \\
\text { tine (West Bank and Gaza); Yemen }\end{array}$ \\
\hline Balkan & $\begin{array}{l}\text { Albania; Bosnia and Herzegovina; Kosovo; Macedonia; Montenegro; } \\
\text { Serbia; Turkey }\end{array}$ \\
\hline Central America & $\begin{array}{l}\text { Anguilla; Antigua and Barbuda; Aruba; Bahamas; Barbados; Belize; } \\
\text { Bermuda; Cayman Islands; Costa Rica; Cuba; Curacao; Dominica; } \\
\text { Dominican Republic; El Salvador; Grenada; Guatemala; Haiti; Hon- } \\
\text { duras; Jamaica; Nicaragua; Panama; St. Kitts and Nevis; St. Lucia; St. } \\
\text { Vincent and the Grenadines; Trinidad and Tobago; Turks and Caicos } \\
\text { Islands; US Virgin Islands; the Virgin Islands, British; Bonaire, Sint } \\
\text { Eustatius and Saba }\end{array}$ \\
\hline Central Asia & $\begin{array}{l}\text { Afghanistan; Bangladesh; Bhutan; Iran; Mongolia; Myanmar; Nepal; } \\
\text { Pakistan }\end{array}$ \\
\hline East Asia & $\begin{array}{l}\text { Brunei Darussalam; Cambodia; China, P.R.: Hong Kong; China, P.R.: } \\
\text { Macao; China, P.R.: Mainland; Indonesia; Japan; Korea, Democratic } \\
\text { People's Rep. of; Korea, Republic of; Lao; Malaysia; Philippines; } \\
\text { Singapore; Taiwan; Thailand; Timor-Leste; Vietnam }\end{array}$ \\
\hline EU, EU-Dependent/Schengen & $\begin{array}{l}\text { Austria; Belgium; Bulgaria; Croatia; Cyprus; Czech Republic; Denmark; } \\
\text { Estonia; Finland; France; Gibraltar; Greece; Hungary; Ireland; Italy; } \\
\text { Latvia; Liechtenstein; Lithuania; Luxembourg; Malta; Monaco; Neth- } \\
\text { erlands; Poland; Portugal; Romania; Slovak Republic; Slovenia; Spain; } \\
\text { Sweden; United Kingdom; Andorra; Faroe Islands; Guernsey; Iceland; } \\
\text { Isle of Man; Jersey; Norway; Switzerland; Vatican }\end{array}$ \\
\hline Former Soviet & $\begin{array}{l}\text { Armenia; Azerbaijan; Belarus; Georgia; Kazakhstan; Kyrgyz Republic; } \\
\text { Moldova; Russian Federation; Tajikistan; Turkmenistan; Ukraine; } \\
\text { Uzbekistan }\end{array}$ \\
\hline North America & Canada; Mexico; United States \\
\hline Oceania & $\begin{array}{l}\text { American Samoa; Australia; Fiji; Marshall Islands; Micronesia; New } \\
\text { Zealand; Papua New Guinea; Samoa }\end{array}$ \\
\hline South America & $\begin{array}{l}\text { Argentina; Bolivia; Brazil; Chile; Colombia; Ecuador; Guiana, French; } \\
\text { Guyana; Paraguay; Peru; Suriname; Uruguay; Venezuela }\end{array}$ \\
\hline South Asia & India; Maldives; Sri Lanka \\
\hline Sub-Saharan-Africa & $\begin{array}{l}\text { Angola; Benin; Botswana; Burkina Faso; Burundi; Cabo Verde; Cam- } \\
\text { eroon; Central African Republic; Chad; Congo, the Democratic Repub- } \\
\text { lic of; Congo, Republic of; Cote d'Ivoire; Equatorial Guinea; Eritrea; } \\
\text { Ethiopia; Gabon; Gambia; Ghana; Guinea; Guinea-Bissau; Kenya; } \\
\text { Lesotho; Liberia; Madagascar; Malawi; Mali; Mauritius; Mozambique; } \\
\text { Namibia; Niger; Nigeria; Rwanda; Senegal; Sierra Leone; South } \\
\text { Africa; South Sudan; Swaziland; Tanzania; Togo; Uganda; Zambia; } \\
\text { Zimbabwe }\end{array}$ \\
\hline
\end{tabular}


Table 10 German imports from different world regions according to UN classification of regions

\begin{tabular}{llc}
\hline Region & Value of imports (USD) & $\begin{array}{c}\text { Share of total } \\
\text { imports } \%\end{array}$ \\
\hline Europe \& Central Asia & $734,210,520,037$ & 69.27 \\
EU & $611,169,066,522$ & 57.66 \\
East Asia and Pacific & $181,769,983,206$ & 17.15 \\
North America & $70,405,560,550$ & 6.64 \\
Latin America \& Caribbean & $23,058,365,423$ & 2.18 \\
South Asia & $16,465,738,748$ & 1.55 \\
MENA & $11,895,097,769$ & 1.12 \\
Sub-Saharan Africa & $11,229,659,277$ & 1.06 \\
Arab & $9,382,801,477$ & 0.89 \\
\hline
\end{tabular}

Source: Own calculation using data from Comtrade

\section{Appendix 2}

See Tables 11, 12, 13 and 14. 


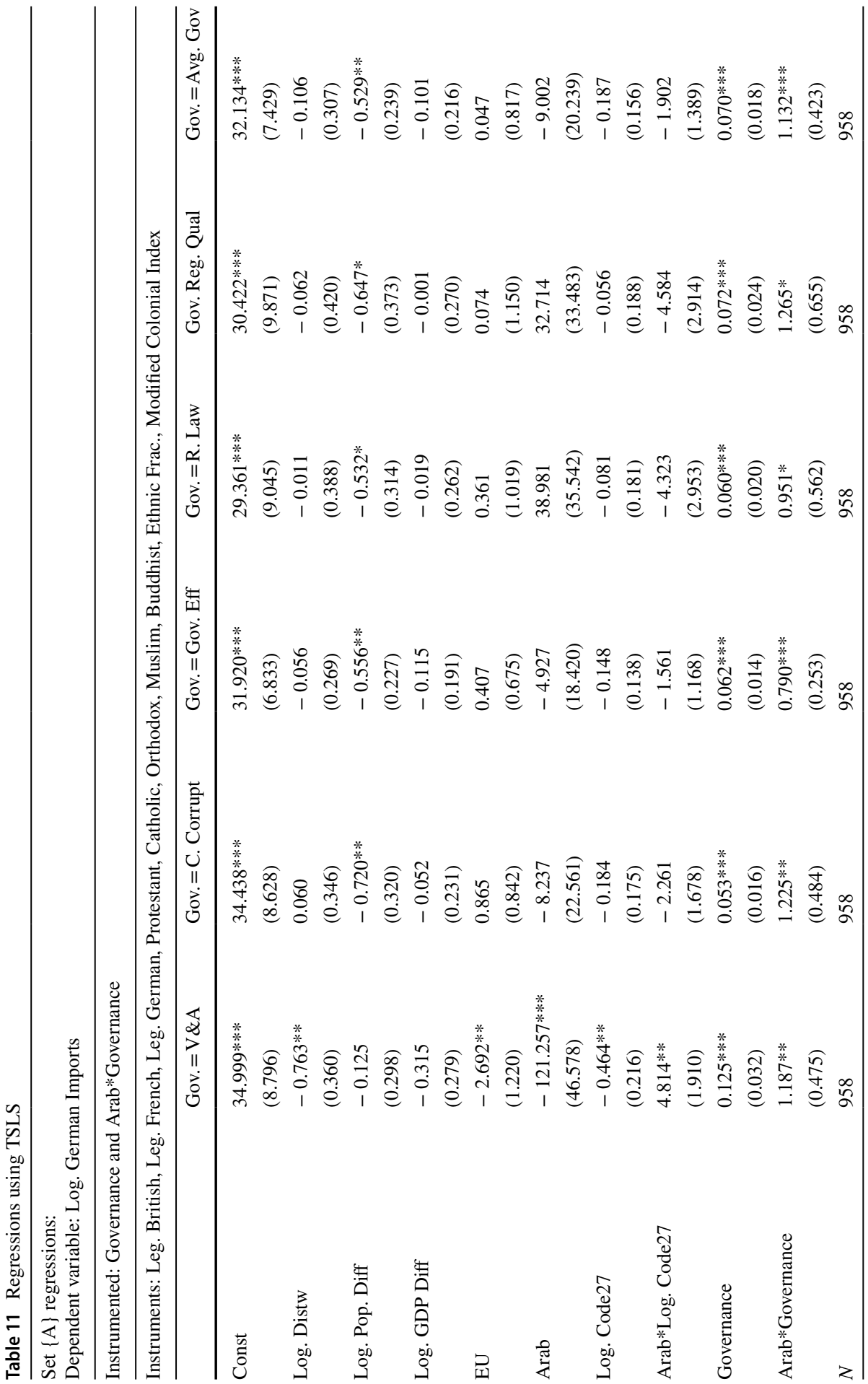

称。 


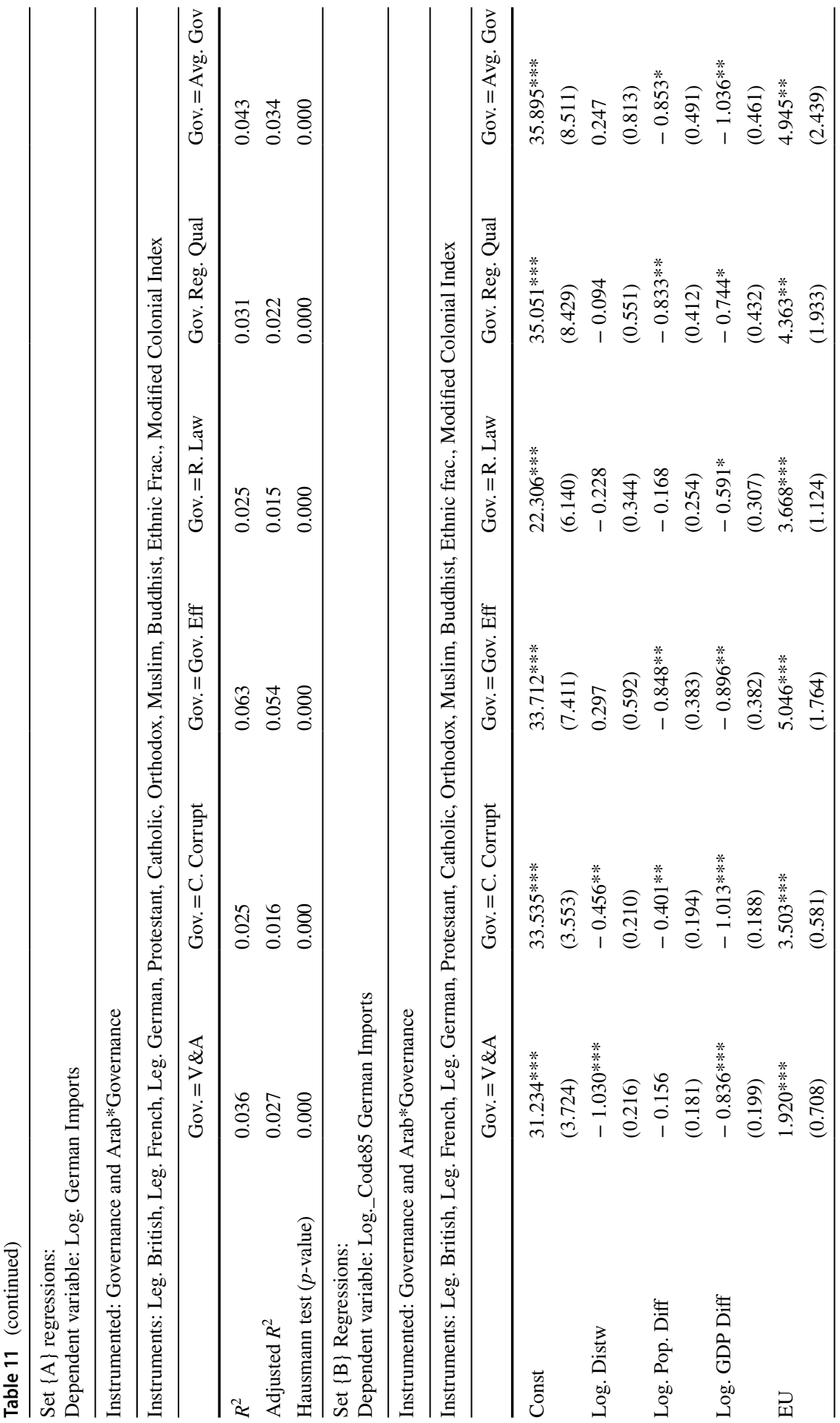




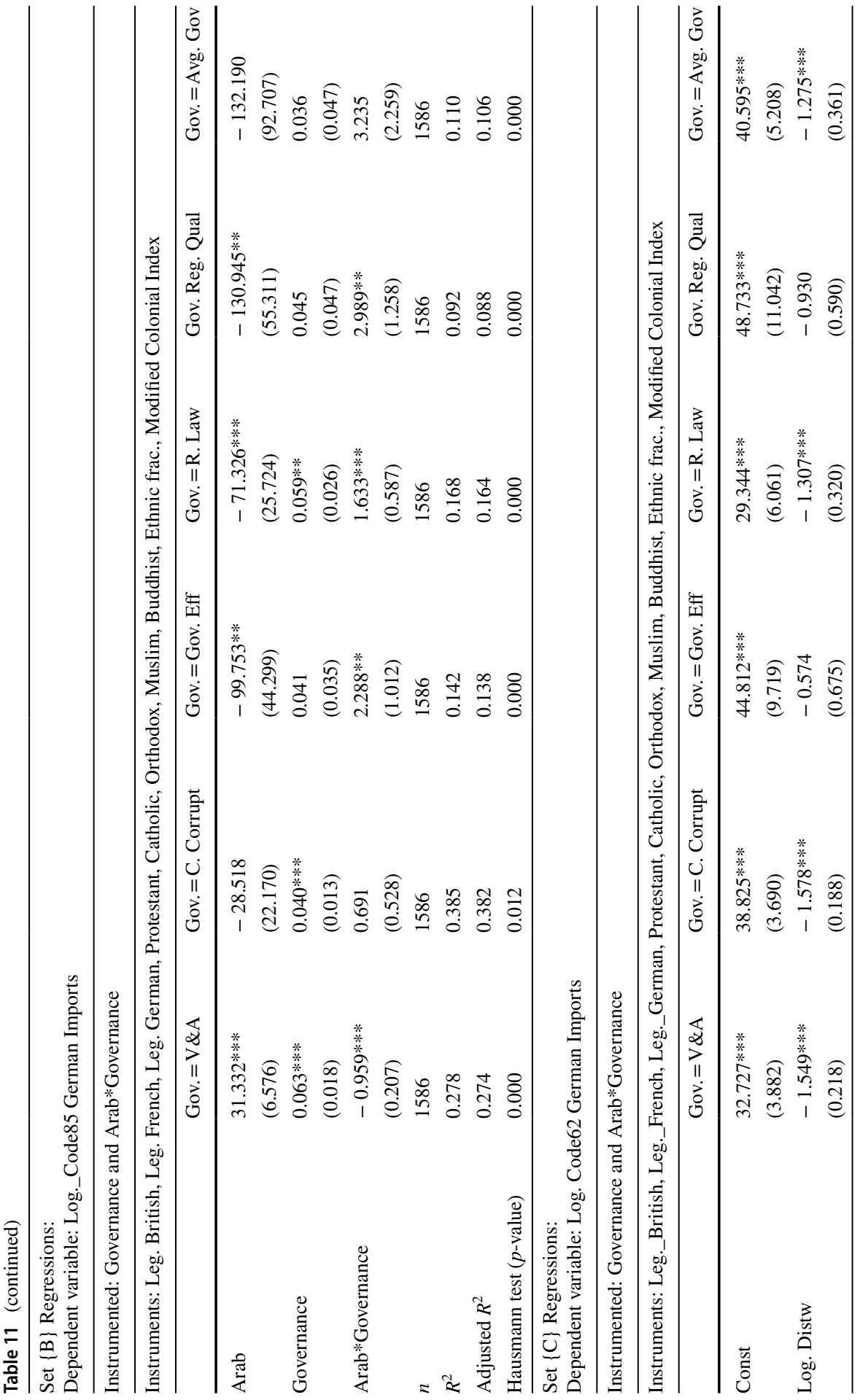

称 


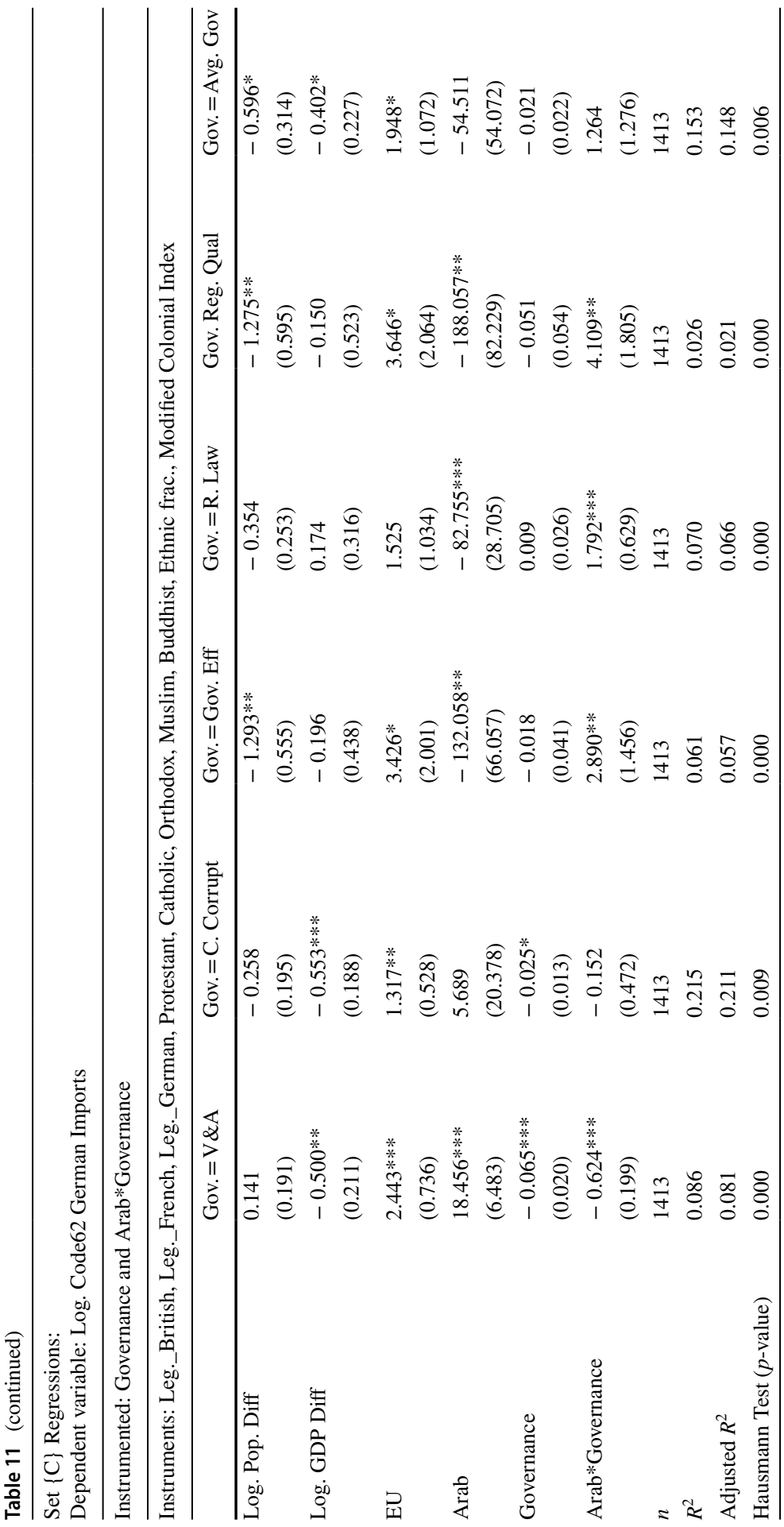




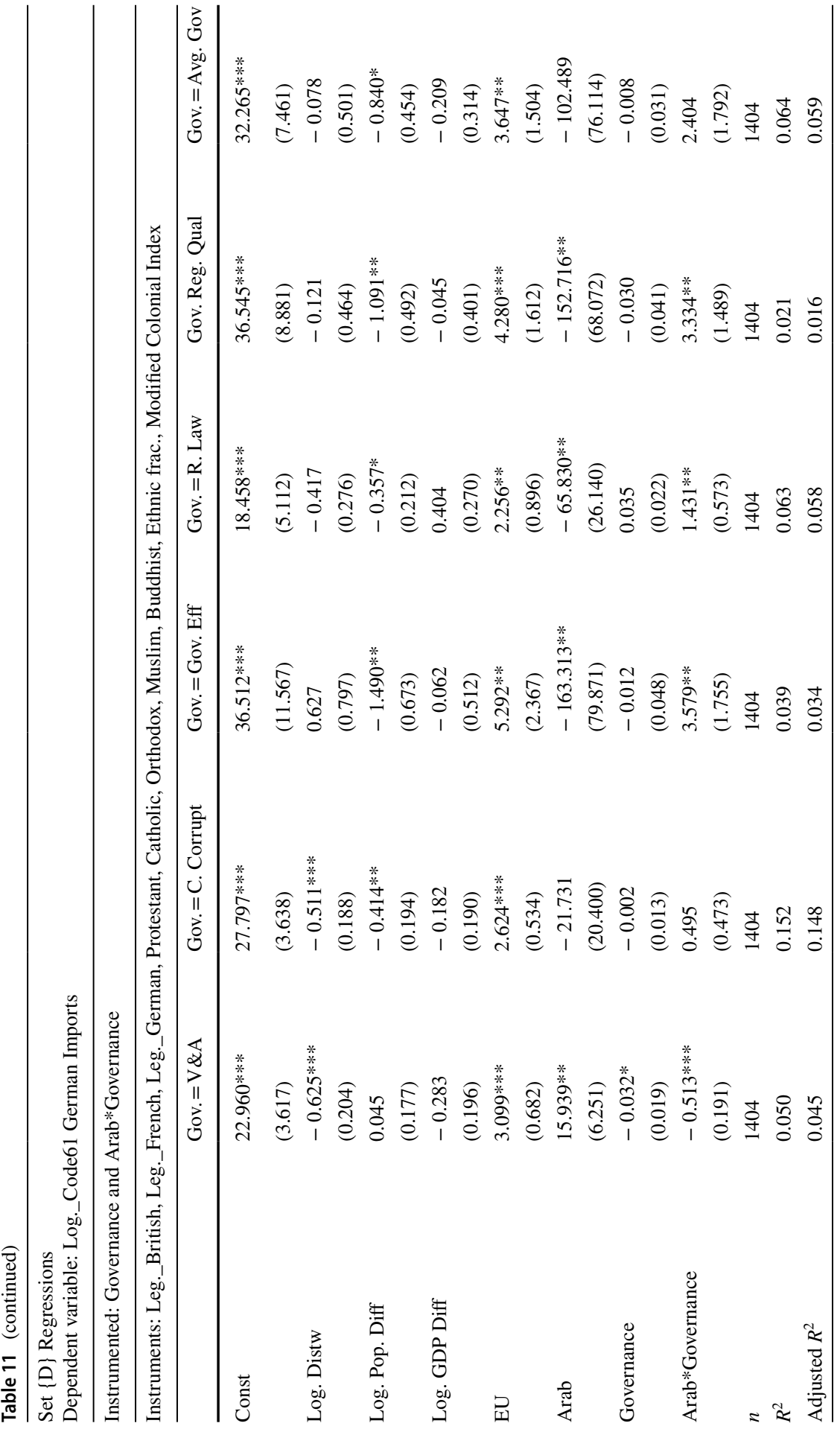

称。 


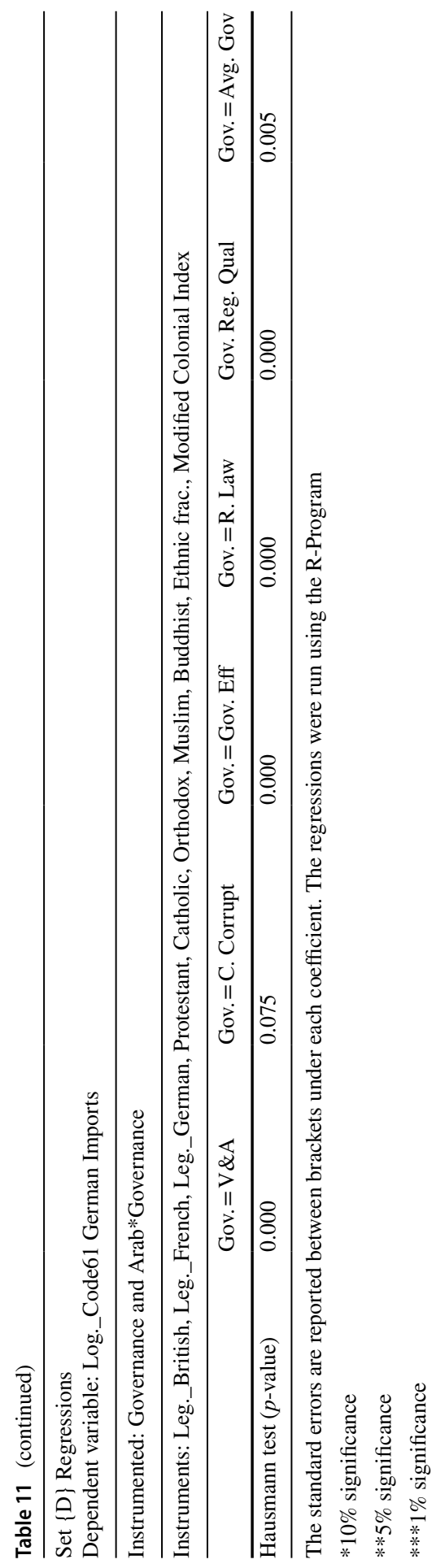




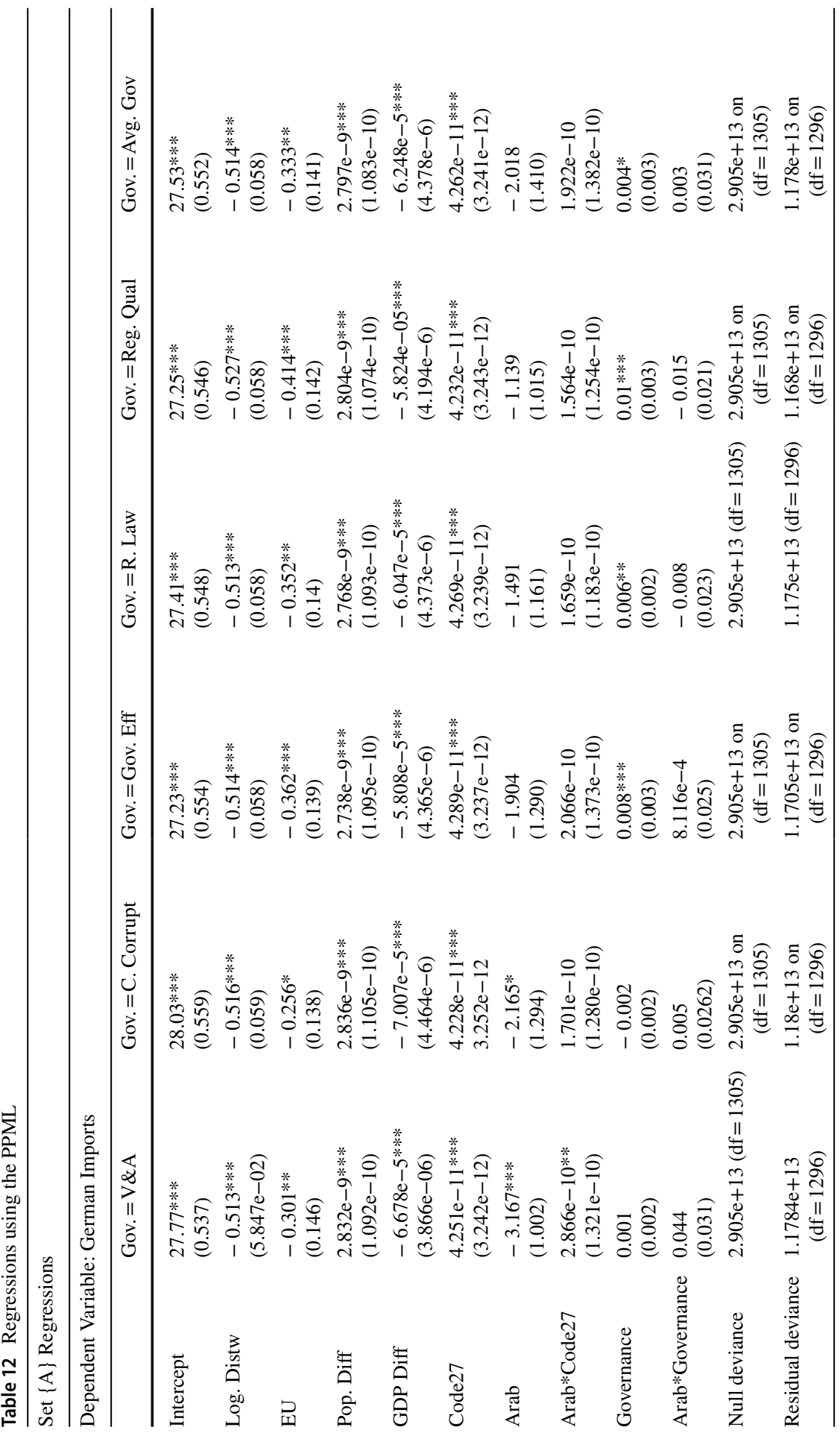

称。 


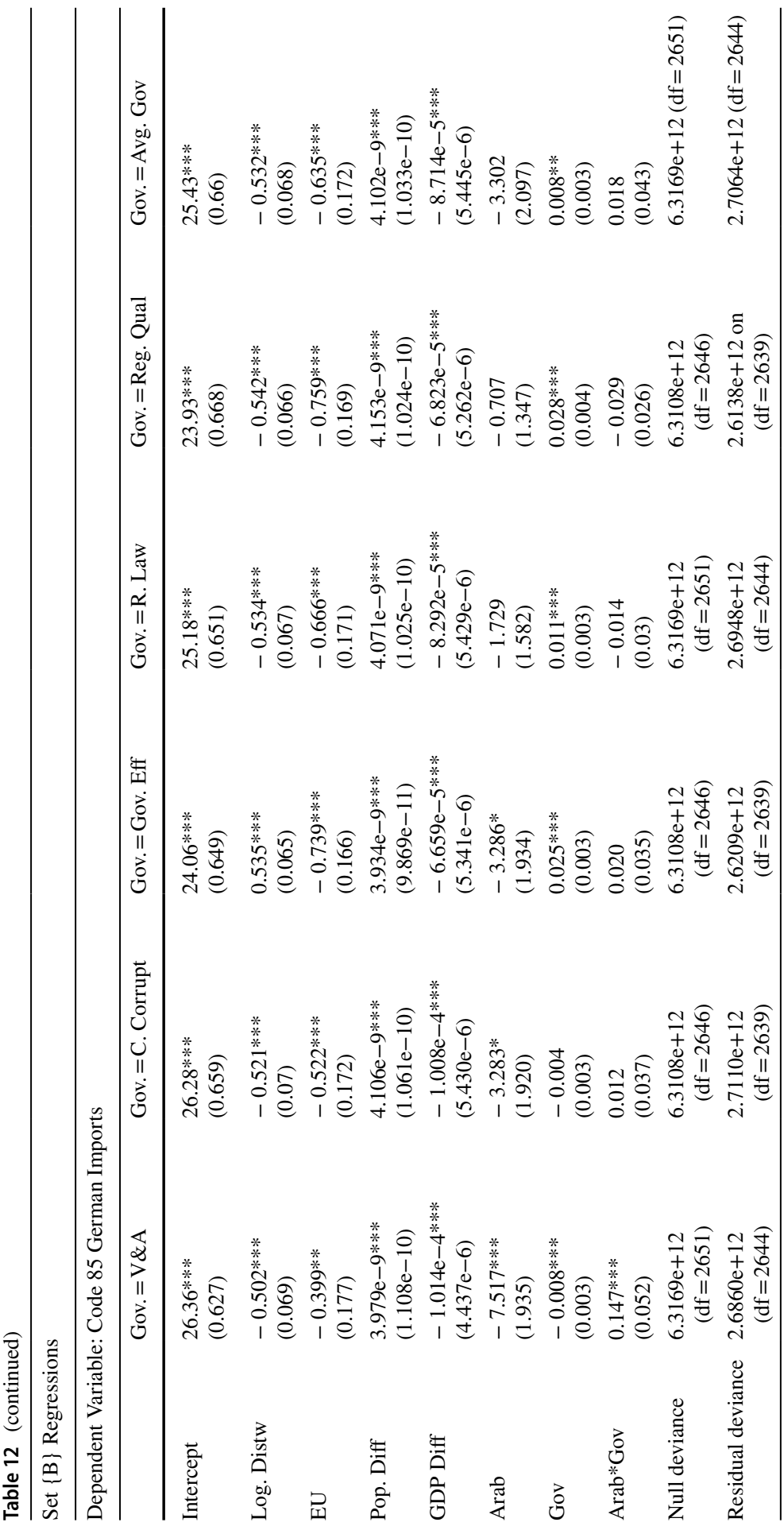




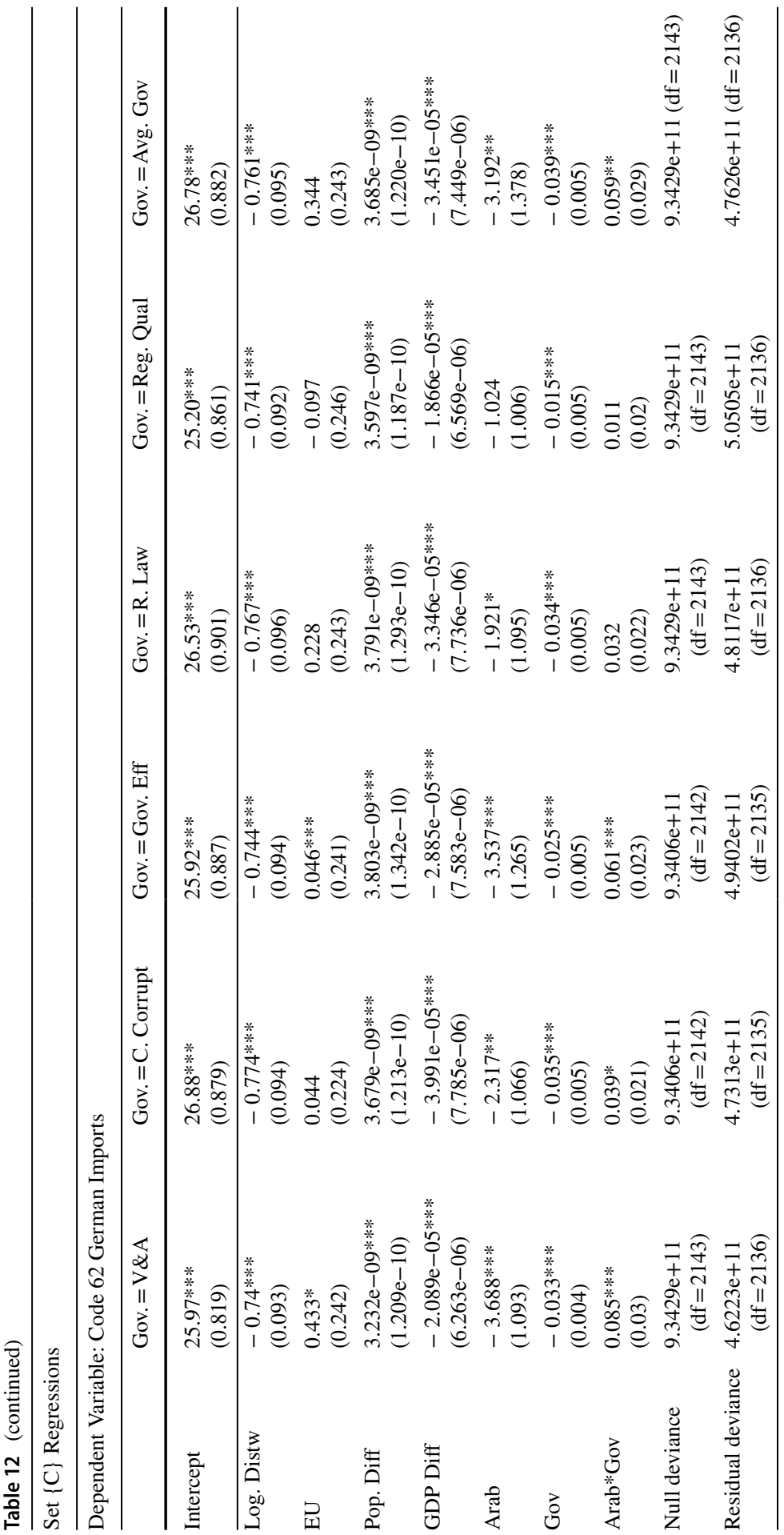

称。 


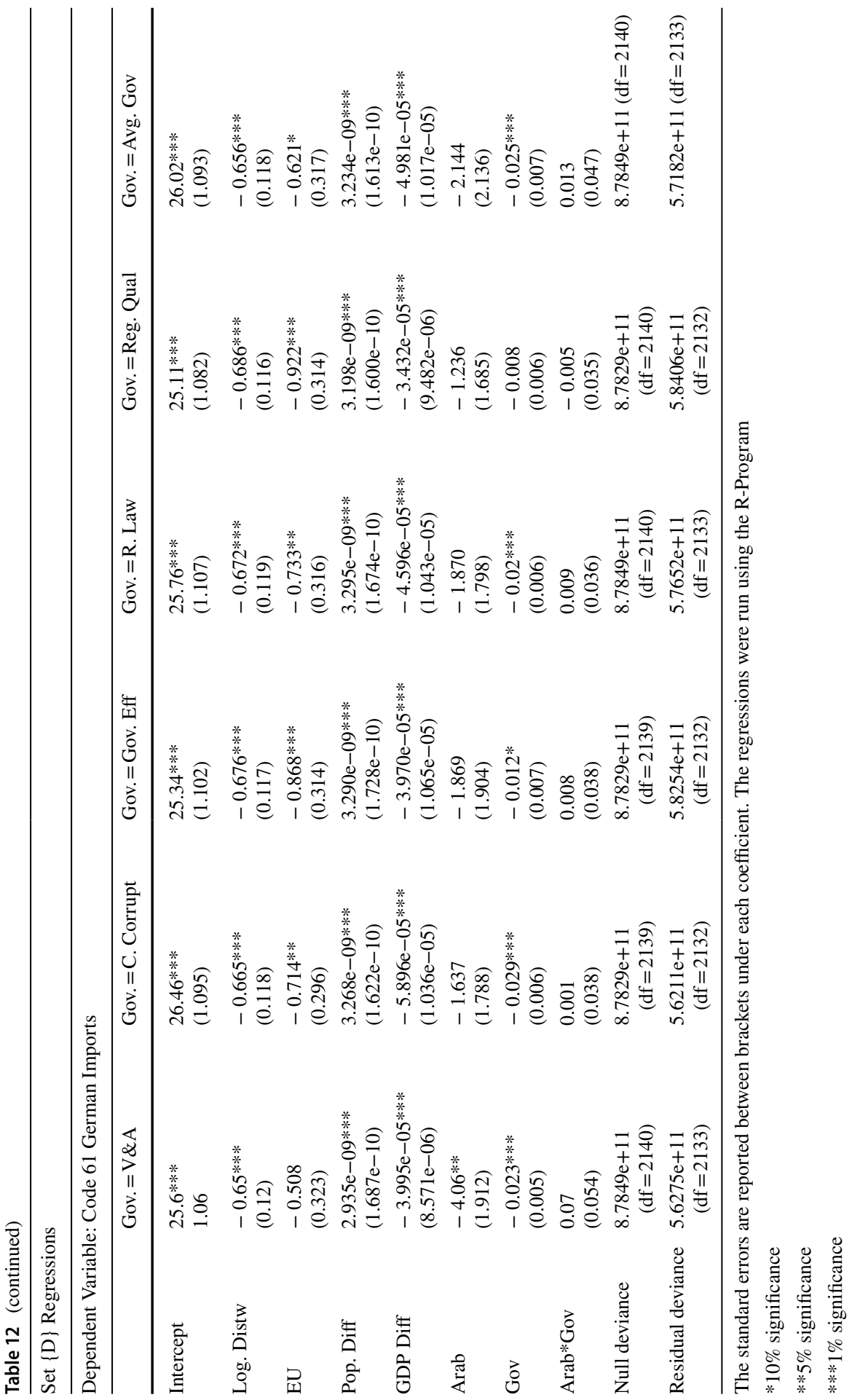


Table 13 The White's test on Heteroskedasticity of regressions run with OLS

\begin{tabular}{lll}
\hline Dependent variable & White's test & $p$-value \\
\hline Total German Imports & $p($ Chi-square $(113)>450.14)$ & 0 \\
German Imports of Code 85 & $p($ Chi-square $(92)>1001.13)$ & 0 \\
German Imports of Code 62 & $p($ Chi-square $(92)>805.77)$ & 0 \\
German Imports of Code 61 & $p($ Chi-square $(92)>755.48)$ & 0
\end{tabular}

Rejecting the null $\left(\mathrm{H}_{0}\right)$ means that heteroskedasticity might exist

Table 14 The Variance Inflation Factors (VIF) of the used independent variables

\begin{tabular}{lclllc}
\hline Variable & VIF & Variable & VIF & Variable & VIF \\
\hline EU & 5.672 & C. Corrupt & 16.944 & Arab*C. Corrupt & 72.957 \\
Log. Pop. Diff & 1.057 & Gov. Eff & 24.844 & Arab*Gov. Eff & 110.12 \\
Log. Dist & 3.952 & Reg. Qual & 13.41 & Arab*Reg. Qual & 86.563 \\
Log. GDP Diff & 1.805 & R. Law & 30.419 & Arab*R. Law & 83.617 \\
Log. Code27 & 1.327 & V\&A & 7.319 & Arab*V\&A & 14.935 \\
Arab*Log. Code27 & 41.143 & Arab & 79.791 & & \\
\hline
\end{tabular}

VIF $>10$ may indicate a collinearity problem

Supplementary Information The online version contains supplementary material available at https://doi. org/10.1057/s41287-021-00462-5.

Acknowledgements The idea of this paper was inspired by my research work done at Bremen University of Applied Sciences (HSB) in the research group led by Prof. Dr. Juliane Brach. Thus, I would like to thank Prof. Brach for the valuable discussions we have engaged in and for supporting my previous research.

Funding Open Access funding enabled and organized by Projekt DEAL.

\section{Declarations}

Conflict of interest The author declares that they have no conflict of interest.

Open Access This article is licensed under a Creative Commons Attribution 4.0 International License, which permits use, sharing, adaptation, distribution and reproduction in any medium or format, as long as you give appropriate credit to the original author(s) and the source, provide a link to the Creative Commons licence, and indicate if changes were made. The images or other third party material in this article are included in the article's Creative Commons licence, unless indicated otherwise in a credit line to the material. If material is not included in the article's Creative Commons licence and your intended use is not permitted by statutory regulation or exceeds the permitted use, you will need to obtain permission directly from the copyright holder. To view a copy of this licence, visit http://creativecommons.org/licen ses/by/4.0/.

\section{References}

Acemoglu, D., S. Johnson, and J.A. Robinson. 2001. The colonial origins of comparative development: An empirical investigation. American economic review 91 (5): 1369-1401. 
Aghion, P., and P. Howitt. 1998. Endogenous growth theory, 2nd ed. Cambridge, London: The MIT Press.

Aghion, P., Y. Algan, P. Cahuc, and A. Shleifer. 2010. Regulation and distrust. The Quarterly Journal of Economics 125 (3): 1015-1049.

Ahmed, M. 2010. Trade competitiveness and growth in the MENA region. In The Arab World Competitiveness Review, 23-26. Washington, DC: IMF.

Al-Atrash, H., \& Yousef, T. (2000). Intra-Arab trade: Is it too little? International Monetary Fund, Working Paper( 00/10).

Alesina, A., A. Devleeschauwer, W. Easterly, S. Kurlat, and R. Wacziarg. 2003. Fractionalization. Journal of Economic Growth 8 (2): 155-194.

Alesina, A., G. Nicoletti, S. Ardagna, and F. Schiantarelli. 2005. Regulation and Investment. Journal of the European Economic Association 3 (4): 791-825.

Aligica, P.D., and V. Tarko. 2014. Crony capitalism: Rent-seeking, institutions, and ideology. Kyklos 67 (2): 156-176.

Anderson, J.E., and D. Marcouiller. 2002. Insecurity and the pattern of trade: An empirical investigation. Review of Economics and Statistics 84 (2): 342-352.

Association of Religion Data Archives (ARDA). (n.d.). Retrieved April 12, 2012, from Quality Data on Religion: https://www.thearda.com/

Barth, J., C. Lin, P. Lin, and F. Song. 2009. Corruption in Bank Lending to firms: Cross-country micro evidence on the beneficial role of competition and information sharing. Journal of Financial Economics 84: 299-329.

Beck, T. D.-K. (2005). Small and medium-size enterprises: Overcoming growth constraints. WB Policy Research, Working Paper, WPS3127.

Behar, A., \& Freund, C. (2011). The trade performance of the Middle East and North Africa. World Bank Middle East and North Africa, Working Paper Series, 53.

Berden, K., J.H. Bergstrand, and E. Van Etten. 2014. Governance and globalization. The World Economy 37 (3): 353-386.

Bhattacharya, R., \& Wolde, H. (2010). Constraints on trade in the MENA region. International Monetary Fund, Working Paper Series, 10/31.

Brach, J. 2007. The Euro-Mediterranean Partnership: The role and impact of the economic and financial dimension. European Foreign Affairs Review 12 (4): 555-579.

Chauffour, J.-P. (2011). Trading integration as a way forward for the Arab World: A regional agenda. World Bank Policy Research, Working Paper Series, 5581.

CIA. (n.d.). Retrieved April 01, 2012, from The World Factbook: https://www.cia.gov/the-world-factb ook/

Cieślik, A., and J. Hagemejer. 2009. Assessing the impact of the EU-sponsored trade liberalization in the MENA countries. Journal of Economic Integration 24 (2): 343-368.

Clague, C., P. Keefer, S. Knack, and M. Olson. 1999. Contract-Intensive Money: Contract Enforcement, Property Rights, and Economic Performance. Journal of Economic Growth 4: 185-211.

Comtrade. (n.d.). Retrieved May 23, 2020, from UN Comtrade Database: https://Comtrade.un.org/

Djankov, S. 2009. The regulation of entry: A survey. The World Bank Research Observer 24 (2): $183-203$.

Djankov, S., R. La Porta, F. de Silanes, and A. Schleifer. 2002. The regulation of entry. The Quarterly Journal of Economics 117 (1): 1-37.

Eaton, J., and A. Tamura. 1994. Bilateralism and regionalism in Japanese and US trade and direct foreign investment patterns. Journal of the Japanese and International Economies 8 (4): 478-510.

European Commission (EC). (n.d.). Trade Policy- Countries and Regions. Retrieved June 01, 2021, from The European Commission: https://ec.europa.eu/trade/policy/countries-and-regions/

Evans, P. 1997. State structures, government-business relations, and economic transformation. In Business and the state in developing countries, ed. S. Maxfield and B.R. Schneider, 63-87. Ithaca, New York: Cornell University.

Evans, P., and J. Rauch. 1999. Bureaucracy and Growth: A cross-National analysis of the effects of "Weberian" state structures on economic growth. American Sociological Review 64 (5): 748-765.

Federal Ministry for Economic Cooperation and Development (BMZ). (n.d.). BMZ 2030 reform strategy- New thinking new direction. Retrieved May 25, 2021, from The Federal Ministry for Economic Cooperation and Development: https://www.bmz.de/en/development-policy/reform-strat egy-bmz-2030 
Federal Ministry for Economic Cooperation and Development (BMZ). (n.d.). Development Policy. Retrieved June 01, 2021, from The German Federal Ministry for Economic Cooperation and Development- BMZ: https://www.bmz.de/en/development-policy

Federal Ministry for Economic Cooperation and Development (BMZ). (n.d.). Global Trade: Fair global trade through development-focused EU trade policy. Retrieved 05 22, 2020, from https://www.bmz. de/en/issues/wirtschaft/welthandel/europaeische_handelspolitik/index.html

Gani, A., and F. Scrimgeour. 2016. New Zealand's trade with Asia and the role of good governance. International Review of Economics \& Finance 42: 36-53.

Glaeser, E., J. Scheinkman, and A. Shleifer. 2003. The injustice of inequality. Journal of Monetary Economics 50: 199-222.

Haggard, S. 2015. The developmental state is dead: long live the developmental state. In Advances in comparative-historical analysis, ed. J. Mahoney and K. Thelen, 39-66. Cambridge: Cambridge University Press.

Hertog, S. 2013. Introduction: The role of MENA business in policy-making and political transitions. In Business politics in the Middle East, ed. S. Hertog, G. Luciani, and M. Valeri, 1-16. London: Hurst Publishers.

Kang, D.C. 2002. Crony capitalism: Corruption and development in South Korea and the Philippines. Cambridge: Cambridge University Press.

Kang, D.C. 2003. Transaction costs and Crony Capitalism in East Asia. Comparative Politics 35 (4): 439-458.

Karam, F., and C. Zaki. 2019. Why don't MENA countries trade more? The curse of deficient institutions. The Quarterly Review of Economics and Finance 73: 56-77.

La Porta, R., F. Lopez-de-Silanes, and A. Shleifer. 2008. The economic consequences of legal origins. Journal of Economic Literature 46 (2): 285-332.

Mankiew, G. 2015. Essentials of Economics, 7th ed. Andover, Hampshire: Cengage.

Martinez-Zarzoso, I., Marquez, L., Parra, M., Said, M., \& Mertzanis, C. (2016). "Exports and Governance: Is MENA different?", in Corporate performance in Transition: The role of business constraints and institutions in the South Mediterranean Region. FEMISE Research Papers, FEM41-08.

Mayer, T., \& Zignago, S. (2011). Notes on CEPII's distances measures: The GeoDist database. CEPII WP, 2011-25.

Méon, P.-G., and K. Sekkat. 2004. Does the quality of institutions limit the MENA's integration in the world economy? World Economy 27 (9): 1475-1498.

Nabli, M.K. 2007a. Long-Term economic development challenges and prospects for the Arab countries. In Breaking the barriers to higher economic growth: Better governance and deeper reforms in the Middle East and North Africa, ed. M. Nabli, 3-28. Washington: The World Bank.

Nabli, M.K. 2007. Restating Arab Economic Reform. In Breaking the barriers to higher economic growth: Better Governance and deeper reforms in the Middle East and North Africa, ed. M.K. Nabli, 89-102. Washington, DC: The World Bank.

$\mathrm{Ng}, \mathrm{F}$., and A. Yeats. 1999. Good governance and trade policy: are they the keys to Africa's global integration and growth? Washington, DC: The World Bank.

Nunn, N. 2007. Relationship-specificity, incomplete contracts, and the pattern of trade. Quarterly Journal of Economics 122 (2): 569-600.

Rock, M., and H. Bonnett. 2004. The comparative politics of corruption: Accounting for the East Asian paradox in empirical studies of corruption, growth and investment. World Development 32 (6): 999-1017.

Sabry, M.I. 2013. State Business Relations: Networks, institutions and their effect on growth and cronyism. Munich: Verlag Dr. Hut.

Sabry, M.I. 2018. State business relations and innovation in the MENA region. Middle East Development Journal 10 (2): 195-224.

Salvatore, D. 1999. International Economics, 6th ed. New York: John Wiley \& Sons Inc.

Santos Silva, J., and S. Tenreyro. 2006. The log of gravity. The Review of Economics and Statistics 88 (4): $641-658$.

Shirley, M. 2005. Institutions and development. In Handbook of new institutional economics, ed. C. Menard and M. Shirley, 609-638. Boston: Springer.

Smith, W. 2004. World Development Report (2005): A better investment climate for everyone. Washington DC: The World Bank. 
The Quality of Government Dataset (QoG)- University of Gothenburg. (n.d.). Data Downloads. Retrieved April 01, 2012, from The Quality of Government Dataset (QoG)- University of Gothenburg: https:// www.gu.se/en/quality-government/qog-data

Wade, R.H. 2018. The developmental state: Dead or alive? Development and Change 49 (2): 518-546.

Wei, S.-J. (1999). Corruption in Economic Development: Beneficial Grease, Minor Annoyance, or Major Obstacle? World Bank policy research, Working Paper, 2048.

World Bank \& International Finance Corporation (WB). 2009. Doing Business 2010-overview. Washington DC: The World Bank.

Yotov, Y.V., R. Piermartini, J.-A. Monteiro, and M. Larch. 2016. An advanced guide to trade policy analysis: The structural gravity model. Geneva: World Trade Organization.

Zanger, S.C. 2000. Good governance and European aid: The impact of political conditionality. European Union Politics 1 (3): 293-317.

Publisher's Note Springer Nature remains neutral with regard to jurisdictional claims in published maps and institutional affiliations. 